\title{
Enduring Reversal of Neuropathic Pain by a Single Intrathecal Injection of Adenosine 2A Receptor Agonists: A Novel Therapy for Neuropathic Pain
}

\author{
Lisa C. Loram, ${ }^{1}$ Jacqueline A. Harrison, ${ }^{1}$ Evan M. Sloane, ${ }^{1}$ Mark R. Hutchinson, ${ }^{1,2}$ Paige Sholar, ${ }^{1}$ Frederick R. Taylor, ${ }^{1}$ \\ Debra Berkelhammer, ${ }^{1}$ Benjamen D. Coats, ${ }^{1}$ Stephen Poole, ${ }^{3}$ Erin D. Milligan, ${ }^{1,4}$ Steven F. Maier, ${ }^{1}$ Jayson Rieger, ${ }^{5}$ \\ and Linda R. Watkins ${ }^{1}$ \\ ${ }^{1}$ Department of Psychology and Center for Neurosciences, University of Colorado at Boulder, Boulder, Colorado 80309-0345, ${ }^{2}$ Discipline of Pharmacology, \\ School of Medical Sciences, University of Adelaide, Adelaide, South Australia 5005, Australia, ${ }^{3}$ National Institute of Biological Standards \\ and Control, Potters Bar, South Mimms, Hertfordshire EN6 3QG, United Kingdom, ${ }^{4}$ Department of Neurosciences, University of New Mexico, Albuquerque, \\ New Mexico 87131, and ${ }^{5}$ PGxHealth, A Division of Clinical Data, Inc., Charlottesville, Virginia 22902
}

Previous studies of peripheral immune cells have documented that activation of adenosine $2 \mathrm{~A}$ receptors $\left(\mathrm{A}_{2 \mathrm{~A}} \mathrm{Rs}\right)$ decrease proinflammatory cytokine release and increase release of the potent anti-inflammatory cytokine, interleukin-10 (IL-10). Given the growing literature supporting that glial proinflammatory cytokines importantly contribute to neuropathic pain and that IL-10 can suppress such pain, we evaluated the effects of intrathecally administered $\mathrm{A}_{2 \mathrm{~A}} \mathrm{R}$ agonists on neuropathic pain using the chronic constriction injury (CCI) model. A single intrathecal injection of the $\mathrm{A}_{2 \mathrm{~A}} \mathrm{R}$ agonists 4-(3-(6-amino-9-(5-cyclopropylcarbamoyl-3,4-dihydroxytetrahydrofuran-2-yl)-9Hpurin-2-yl)prop-2-ynyl)piperidine-1-carboxylic acid methyl ester (ATL313) or 2-p-(2-carboxyethyl)phenethylamino-5'- $N$-ethylcarboxamido adenosine $\mathrm{HCl}$ (CGS21680), $10-14 \mathrm{~d}$ after CCI versus sham surgery, produced a long-duration reversal of mechanical allodynia and thermal hyperalgesia for at least 4 weeks. Neither drug altered the nociceptive responses of sham-operated controls. An $A_{2 A} R$ antagonist [ZM241385 (4-(2-[7-amino-2-(2-furyl)(1,2,4)triazolo(2,3-a)(1,3,5)triazin-5-ylamino]ethyl)phenol)] coadministered intrathecally with ATL313 abolished the action of ATL313 in rats with neuropathy-induced allodynia but had no effect on allodynia in the absence of the $\mathrm{A}_{2 \mathrm{~A}} \mathrm{R}$ agonist. ATL313 attenuated CCI-induced upregulation of spinal cord activation markers for microglia and astrocytes in the L4-L6 spinal cord segments both 1 and 4 weeks after a single intrathecal ATL313 administration. Neutralizing IL-10 antibodies administered intrathecally transiently abolished the effect of ATL313 on neuropathic pain. In addition, IL-10 mRNA was significantly elevated in the CSF cells collected from the lumbar region. Activation of $\mathrm{A}_{2 \mathrm{~A}} \mathrm{Rs}$ after intrathecal administration may be a novel, therapeutic approach for the treatment of neuropathic pain by increasing IL-10 in the immunocompetent cells of the CNS.

\section{Introduction}

Neuropathic pain, resulting from nerve injury or inflammation, affects $\sim 4$ million people in the United States alone (Taylor, 2006) and remains poorly managed by currently available therapeutics. Most of these therapeutics specifically target neurons. However, spinal glia (astrocytes and microglia) play an important role in facilitating and maintaining neuropathic pain in animal models (Watkins et al., 2007). After the initial injury or inflammation, neuronal central sensitization occurs and normally surveying microglial cells become activated to a reactive

\footnotetext{
Received July 14, 2009; revised Sept. 4, 2009; accepted 0ct. 9, 2009.

This work was supported by PGXHealth, LLC, a division of Clinical Data, Inc.; the American Pain Society Future Leaders in Pain Management Small Grants Program; International Association for the Study of Pain International Collaborative Grant; American Australian Association Merck Company Foundation Fellowship; National Health and Medical Research Council C. J. Martin Fellowship ID 465423 (M.R.H.); and National Institutes of Health Grants DA02422 and DA017670. We thank Avigen for the purification of anti-IL-10.

Correspondence should be addressed to Dr. Lisa C. Loram, Department of Psychology and Center for Neurosciences, UCB 345, University of Colorado at Boulder, Boulder, C0 80309-0345. E-mail: lisa.loram@colorado.edu. D0I:10.1523/JNEUROSCI.3447-09.2009

Copyright $\odot 2009$ Society for Neuroscience ～0270-6474/09/2914015-11\$15.00/0
}

state (Hanisch and Kettenmann, 2007). Activated glial cells release proinflammatory cytokines [interleukin- $1 \beta$ (IL-1 $\beta)$, IL-6, tumor necrosis factor- $\alpha$ (TNF- $\alpha)]$, chemokines, and other inflammatory mediators such as prostaglandins, reactive oxygen species, and nitric oxide, contribute to the maintenance of central sensitization (Watkins et al., 2007). Recent studies have identified that decreasing spinal proinflammatory cytokines or increasing anti-inflammatory cytokines is effective in attenuating neuropathyinduced allodynia (DeLeo and Yezierski, 2001; Milligan et al., 2006; Watkins et al., 2007). An ideal pharmacological treatment for neuropathic pain would be to avoid short-term blockade of the downstream effects of glial activation and neuronal hyperexcitability, and instead "reset" activated glia back to their basal, surveying state or to an alternatively activated anti-inflammatory state (Gordon, 2003). As yet, no candidate drug has been identified that induces such changes.

One potential candidate for such a drug may be an agonist at a select adenosine receptor subtype. Adenosine can bind four different receptors: adenosine 1 receptor $\left(A_{1} R\right), A_{2 A} R, A_{2 B} R$, and $A_{3} R$. Most work investigating the effects of adenosine in pain 
models have used adenosine or nonselective agonists and antagonists, which will target multiple adenosine receptors. In addition, some studies have explored the effect of $A_{1} R$ agonists, as $A_{1}$ Rs are found predominantly on neurons (Hasko et al., 2007) and $\mathrm{A}_{1} \mathrm{R}$ agonists are antinociceptive in a number of different pain models (Lee and Yaksh, 1996; Yamamoto et al., 2003; Zahn et al., 2007).

$A_{2 A} R$ agonists may be of special interest. A growing body of literature is presenting $\mathrm{A}_{2 \mathrm{~A}} \mathrm{R}$ agonists as having potent antiinflammatory effects on peripheral immune cells, including suppression of proinflammatory cytokines and enhanced production of the anti-inflammatory cytokine, IL-10 (Hasko and Cronstein, 2004). Such a pattern is consistent with $\mathrm{A}_{2 \mathrm{~A}} \mathrm{Rs}$ being $\mathrm{G} \alpha$ s-linked receptors that stimulate adenylyl cyclase resulting in increased cAMP production (Hasko et al., 2007). In addition to peripheral immune cells, $A_{2 A}$ Rs are found on a wide variety of cell types within the CNS (Dare et al., 2007). Although one cannot rule out the possibility of $\mathrm{A}_{2 \mathrm{~A}} \mathrm{R}$ agonists exerting at least some of their effects on neurons, microglia are the surveying immunocompetent macrophages of the CNS, and astrocytes have immunogenic properties (Ren and Dubner, 2008). Therefore, it is possible that $\mathrm{A}_{2 \mathrm{~A}} \mathrm{R}$ activation on microglia and astrocytes may produce anti-inflammatory effects within the spinal cord, thus alleviating allodynia from chronic pain states. The present series of studies was designed to explore this possibility through the use of $\mathrm{A}_{2 \mathrm{~A}} \mathrm{R}$ agonists.

\section{Materials and Methods}

\section{Subjects}

Pathogen-free male Sprague Dawley rats (325-350 g; Harlan Laboratories) were used for all experiments. Rats were housed two per cage with standard rat chow and water ad libitum. Housing was in a temperaturecontrolled environment $\left(23 \pm 2^{\circ} \mathrm{C}\right)$ with a $12 \mathrm{~h}$ light/dark cycle (lights on at 7:00 A.M.). All procedures occurred in the light phase. All animals were allowed 1 week of acclimation to the colony rooms before experimentation. The Institutional Animal Care and Use Committee of the University of Colorado at Boulder approved all procedures.

\section{Drugs}

The $\mathrm{A}_{2 \mathrm{~A}} \mathrm{R}$ agonist 4-(3-(6-amino-9-(5-cyclopropylcarbamoyl-3,4dihydroxytetrahydrofuran-2-yl)-9H-purin-2-yl)prop-2-ynyl)piperidine-1carboxylic acid methyl ester (ATL313) was a gift from PGxHealth, a division of Clinical Data. The half-life of ATL313 is $<30 \mathrm{~min}$ (Moore et al., 2008). The $\mathrm{A}_{2 \mathrm{~A}}$ agonist 2-p-(2-carboxyethyl)phenethylamino- $5^{\prime}-N$ ethylcarboxamido adenosine $\mathrm{HCl}$ (CGS21680) and the $\mu$ (naloxonazine), $\kappa$ (nor-binaltrophimine), and $\delta$ (naltrindole) selective opioid receptor antagonists were purchased from Sigma-Aldrich. The $\mathrm{A}_{2 \mathrm{~A}} \mathrm{R}$ selective antagonist 4-(2-[7-amino-2-(2-furyl) $(1,2,4) \operatorname{triazolo}(2,3-\mathrm{a})(1,3,5)$ triazin5 -ylamino]ethyl)phenol (ZM24385) was purchased from Tocris Bioscience. All of the adenosine agonists and antagonists were dissolved in DMSO to create $10 \mathrm{~mm}$ stock concentrations and stored at $-20^{\circ} \mathrm{C}$. Fresh aliquots were diluted to the appropriate concentration in sterile endotoxin-free isotonic saline (Abbot Laboratories). The opioid antagonists were made fresh immediately before injections. The vehicle for the adenosine agonists and antagonists was $0.01 \%$ DMSO saline solution given the dilution of the drugs from stock was 1:10,000 to yield a $1 \mu \mathrm{M}$ dose. The vehicle for the opioid antagonists was $0.9 \%$ saline. All vehicle injections were administered equivolume to the drugs being tested. Rat IL-10 neutralizing antibodies were raised in sheep at the National Institute of Biological Standards and Control (South Mimms, Hertfordshire, UK) and purified by Avigen. Normal sheep IgG was used as a control (Sigma-Aldrich).

\section{von Frey test for mechanical allodynia}

Rats were habituated to the testing apparatus for 4 consecutive days before testing. The von Frey test was performed on the plantar surface of each hindpaw within the region of sciatic nerve innervation, as described previously (Milligan et al., 2000). A logarithmic series of 10 calibrated Semmes-Weinstein monofilaments (Stoelting) were sequentially applied (from low- to high-intensity threshold) to the left and right hindpaws in random order, each for $8 \mathrm{~s}$ at constant pressure to determine the stimulus intensity threshold stiffness required to elicit a paw withdrawal response. Log stiffness of the hairs is determined by $\log _{10}($ milligrams $\times 10$ ). The range of monofilaments used in these experiments (0.407-15.136 g) produces a logarithmically graded slope when interpolating a $50 \%$ response threshold of stimulus intensity [expressed as $\log _{10}$ (milligrams $X$ 10)] (Chaplan et al., 1994). The stimulus intensity threshold to elicit a paw withdrawal response was used to calculate the $50 \%$ paw withdrawal threshold (absolute threshold) using the maximum-likelihood fit method to fit a Gaussian integral psychometric function (Harvey, 1986). This method normalizes the withdrawal threshold for parametric analyses (Harvey, 1986). The behavioral testing was performed blind with respect to the drug administration.

\section{Modified Hargreaves test for thermal hyperalgesia}

Thresholds for behavioral response to heat stimuli applied separately to the tail and each hindpaw were assessed using a modified Hargreaves test (Hargreaves et al., 1988). Baseline withdrawal values were calculated from an average of three consecutive withdrawal latencies of the tail and left and right hindpaws. A cutoff time of $20 \mathrm{~s}$ was imposed to avoid tissue damage. As with the von Frey test, this behavioral testing was performed blind with respect to the drug administration.

\section{Surgery}

Chronic constriction injury (CCI) (Bennett and Xie, 1988) of the left sciatic nerve was aseptically performed under isoflurane anesthesia. Four ligatures of 4-0 chromic gut were tied loosely around the left sciatic nerve at the level of the midthigh, as described previously (Milligan et al., 2004).

\section{Acute intrathecal injections}

Animals were lightly anesthetized with isoflurane. The lumbar region was shaved and cleaned. An 18 gauge guide needle, with the hub removed, was inserted into the L5/6 intervertebral space. A PE-10 catheter was inserted into the guide needle, premarked such that the proximal end of the PE-10 tubing rested over the L4-L6 lumbar spinal cord. All drugs were administered over $20 \mathrm{~s}$ ( $1 \mu \mathrm{l}$ of drug followed by $2 \mu \mathrm{l}$ of sterile saline flush) with a $30 \mathrm{~s}$ delay before removing the catheter and guide needle. Each animal was anesthetized for a maximum of $5 \mathrm{~min}$, and none incurred observable neurological damage from the procedure.

\section{Immunohistochemistry}

The $0.6 \mathrm{~mm}$ pieces of the L4-L6 lumbar spinal cord were sectioned (20 $\mu \mathrm{m})$, mounted onto gelatin-subbed slides, and treated with $0.03 \% \mathrm{H}_{2} \mathrm{O}_{2}$ in Tris-buffered saline for $15 \mathrm{~min}$. Sections were incubated overnight in primary antibodies for monoclonal mouse anti-rat OX-42 (1:100; BD Biosciences Pharmingen) and monoclonal mouse anti-rat glial fibrillary acidic protein (GFAP) (1:100; ImmunO). After washing, the sections were incubated with biotinylated secondary antibodies (1:200; Jackson ImmunoResearch) for $2 \mathrm{~h}$ at room temperature. The sections were washed followed by $2 \mathrm{~h}$ incubation in ABC (1:400; Vector Laboratories), washed, and reacted with 3,3'-diaminobenzadine tetrahydrochloride (DAB) (Sigma-Aldrich). Glucose oxidase and D-glucose were used to generate hydrogen peroxide. Nickeleous ammonium sulfate was used with the $\mathrm{DAB}$ reaction to optimize the reaction product. Sections were dried overnight and then dehydrated with graded alcohol, cleared in Histoclear, and coverslipped with Permount. From each animal's spinal cord, five to seven sections within the L4-L6 region were included in the analysis. The ipsilateral and contralateral dorsal horn to the side of injury, of each section, was captured at $10 \times$ magnification as a tiff file. Each image was analyzed, under blinded conditions, using NIH ImageJ using a gray scale. The signal pixels within the dorsal horn were identified above 3.5 SDs beyond a control region (lateral column of the cord). The integrated densitometry was calculated as the number of pixels and the average gray scales above the set background (Chacur et al., 2004).

RNA isolation and CDNA synthesis

Total RNA from the lumbar spinal cord was extracted using the standard phenol/chloroform extraction with TRIzol Reagent (Invitrogen) accord- 
Table 1. Primer sequences

\begin{tabular}{|c|c|c|}
\hline Gene & Primer sequence $\left(5^{\prime}-3^{\prime}\right)$ & GenBank accession no. \\
\hline \multirow[t]{2}{*}{$\beta$-actin } & AGAGGCATCCTGACCCTGAA (forward) & NM_031144 \\
\hline & GCTCATTGTAGAAAGTGTGGT (reverse) & \\
\hline \multirow[t]{2}{*}{$\beta$-actin (i-s) } & TTCCTTCCTGGGTATGGAAT (forward) & \\
\hline & GAGGAGCAATGATCTTGATC (reverse) & \\
\hline \multirow[t]{2}{*}{$T N F-\alpha$} & CTTCAAGGGACAAGGCTG (forward) & D00475 \\
\hline & GAGGCTGACTTTCTCCTG (reverse) & \\
\hline \multirow[t]{2}{*}{$\operatorname{TNF}-\alpha(i-s)$} & CAAGGAGGAGAAGTTCCCA (forward) & \\
\hline & TTGGTGGTTTGCTACGACG (reverse) & \\
\hline \multirow[t]{2}{*}{ IL-10 } & TAAGGGTTACTTGGGTTGCC (forward) & NM_012854 \\
\hline & TATCCAGAGGGTCTTCAGC (reverse) & \\
\hline \multirow[t]{2}{*}{$I L-10(i-s)$} & GGACTTTAAGGGTTACTTGGG (forward) & \\
\hline & AGAAATCGATGACAGCGTCG (reverse) & \\
\hline
\end{tabular}

$i$-s, Intron-spanning primers generated to reduce genomic interference for the CSF cells that did not receive DNAse treatment.

ing to the manufacturer's guidelines. Samples were treated with DNase to remove any contaminating DNA (Ambion). Total RNA was reverse transcribed into cDNA using Superscript II First-Strand Synthesis System (Invitrogen). First-strand cDNA was synthesized using total RNA, random hexamer primer $(5 \mathrm{ng} / \mu \mathrm{l})$ and $1 \mathrm{~mm}$ dNTP mix (Invitrogen) and incubated at $65^{\circ} \mathrm{C}$ for $5 \mathrm{~min}$. After $2 \mathrm{~min}$ incubation on ice, a cDNA synthesis buffer [ $5 \times$ reverse transcription $(\mathrm{RT})$ buffer; Invitrogen] and dithiothreitol $(10 \mathrm{~mm})$ was added and incubated at $25^{\circ} \mathrm{C}$ for $2 \mathrm{~min}$. Reverse transcriptase (Superscript III; $200 \mathrm{U}$; Invitrogen) was added to a total volume of $20 \mu \mathrm{l}$ and incubated for $10 \mathrm{~min}$ at $25^{\circ} \mathrm{C}, 50 \mathrm{~min}$ at $42^{\circ} \mathrm{C}$, and deactivating the enzyme at $70^{\circ} \mathrm{C}$ for $15 \mathrm{~min}$. cDNA was diluted twofold in nuclease-free water and stored at $-80^{\circ} \mathrm{C}$. The cells within the CSF were processed into cDNA using a Cells-Direct III cDNA synthesis kit (Invitrogen) according to the manufacturer's guidelines. Briefly, after washing the cells in $100 \mu$ l of Dulbecco's PBS, the CSF cells were lysed in $11 \mu \mathrm{l}$ of lysis buffer and lysis solution for $10 \mathrm{~min}$ on ice. Ten microliters of cell lysate were added to $1 \mu \mathrm{l}$ of RNase inhibitor and incubated at $75^{\circ} \mathrm{C}$ for $10 \mathrm{~min}$. First-strand cDNA was synthesized by adding $2 \mu \mathrm{l}$ of oligo$\mathrm{dT}, 1 \mu \mathrm{l}$ of $\mathrm{dNTP}$, and $7.8 \mu \mathrm{l}$ of nuclease-free water to the cell lysate and incubating at $70^{\circ} \mathrm{C}$ for $5 \mathrm{~min}$. After $2 \mathrm{~min}$ on ice, $6 \mu$ l of $5 \times$ RT buffer, $1 \mu \mathrm{l}$ of RNase inhibitor, $1 \mu \mathrm{l}$ of Superscript III, and $1 \mu \mathrm{l}$ of dithiothreitol was added to the cell lysate and incubated at $50^{\circ} \mathrm{C}$ for $50 \mathrm{~min}, 5 \mathrm{~min}$ for $85^{\circ} \mathrm{C}$. Finally, 1 $\mu l$ of RNase $\mathrm{H}$ was added and incubated at $37^{\circ} \mathrm{C}$ for $20 \mathrm{~min}$. All cDNA was stored at $-80^{\circ} \mathrm{C}$ until real-time PCR (RT-PCR) was performed.

\section{$R T-P C R$}

Primer sequences were obtained from the GenBank at the National Center for Biotechnology Information (www.ncbi.nlm.nih.gov) and are displayed in Table 1. Primers were generated to span an intron to eliminate genomic interference in the CSF samples that did not receive DNase treatment. The CSF samples were approached in this manner as the RNA isolation through to cDNA synthesis is completed in the same tube. Therefore, genomic variability was minimized by not doing a DNase treatment but rather designing primer sequences that spanned an intron. Amplification of the cDNA was performed, in a blinded procedure, using Quantitect SYBR Green PCR kit (QIAGEN) in iCycler iQ 96-well PCR plates (Bio-Rad) on a MyiQ single Color Real-Time PCR Detection System (Bio-Rad). The reaction mixture $(26 \mu \mathrm{l})$ was composed of QuantiTect SYBR Green (containing fluorescent dye SYBR Green I, $2.5 \mathrm{~mm}$ $\mathrm{MgCl}_{2}, \mathrm{dNTP}$ mix, and Hot Start Taq polymerase), $10 \mathrm{~nm}$ fluorescein, $500 \mathrm{~nm}$ each forward and reverse primer (Invitrogen), nuclease-free water, and $1 \mu \mathrm{l}$ of cDNA from each sample. Each sample was measured in duplicate. The reactions were initiated with a hot start at $95^{\circ} \mathrm{C}$ for $25 \mathrm{~min}$, followed by 40 cycles of $15 \mathrm{~s}$ at $94^{\circ} \mathrm{C}$ (denaturation), $30 \mathrm{~s}$ at $55-60^{\circ} \mathrm{C}$ (annealing), and $30 \mathrm{~s}$ at $72^{\circ} \mathrm{C}$ (extension). Melt curve analyses were conducted to assess uniformity of product formation, primer-dimer formation, and amplification of nonspecific products. The PCR product was monitored in real-time, using the SYBR Green I fluorescence, using the MyiQ Single-Color Real-Time PCR Detection System (Bio-Rad). Threshold for detection of PCR product was set in the log-linear phase of amplification and the threshold cycle $\left(C_{T}\right)$ was determined for each re- action. The level of the target mRNA was quantified relative to the housekeeping gene ( $\beta$-actin) using the comparative $C_{T}\left(\Delta C_{T}\right)$ method. The expression of $\beta$-actin was not significantly different between treatments.

\section{Statistical analysis}

Behavioral measures were normalized as described above and analyzed using repeated-measures two-way ANOVA with time and treatment as main effects. The integrated density from the histology and RT-PCR data were analyzed using a two-way ANOVA with surgery and drug administration as main effects. Bonferroni's post hoc tests were used where appropriate, and $p<0.05$ was considered statistically significant. For ease of reading, the basic statistical values are shown in the text while the more extensive statistical information can be found in the figure legends.

\section{Experimental procedures}

Experiment 1: effect of $A_{2 A} R$ agonists on peripheral neuropathy-induced mechanical allodynia and thermal hyperalgesia. Baseline behavioral measures were recorded after $4 \mathrm{~d}$ of $40 \mathrm{~min} / \mathrm{d}$ habituation to the testing environment. CCI or sham surgery was then conducted, and behavioral responses to mechanical stimuli or thermal stimuli were tested, in separate groups of rats, at 4 and $10 \mathrm{~d}$ after surgery. At 10-14 d after surgery, an acute intrathecal administration of $\operatorname{ATL313}(0.1$ or $1 \mu \mathrm{M}$ in $1 \mu \mathrm{l})$, CGS21680 ( 1 or $10 \mu \mathrm{M}$ in $1 \mu \mathrm{l})$, or equivolume vehicle was given $(n=$ 6-7 rats per group) in groups tested for mechanical allodynia. Based on these results, an acute intrathecal administration of either ATL313 (1 $\mu \mathrm{M})$ or vehicle was given to CCI and sham groups tested for thermal hyperalgesia. For both the mechanical and thermal testing, behavioral responses were measured 4, 24, $72 \mathrm{~h}$, and weekly for 6 weeks after intrathecal drug administration.

Experiment 2: effect of $A_{2 A} R$ antagonism on the $A_{2 A}$ R agonist effect. As in experiment 1 , baseline behavioral measures were performed after $4 \mathrm{~d}$ of $40 \mathrm{~min} / \mathrm{d}$ habituation to the testing environment. CCI was conducted and behavioral responses to mechanical stimuli were tested 4 and $10 \mathrm{~d}$ after surgery. At 10-14 d after surgery, an acute intrathecal administration of ATL313 $(1 \mu \mathrm{M})$ or vehicle $(1 \mu \mathrm{l})$ was given with either ZM241385 (10 $\mu \mathrm{M} ; \mathrm{A}_{2 \mathrm{~A}} \mathrm{R}$ antagonist) or vehicle $(1 \mu \mathrm{l} ; n=6$ rats per group). A 10 -fold higher dose of the antagonist was used to ensure complete blockade of $A_{2 A}$ Rs. Behavioral responses were measured 1, 2, 3, 4, 6, and $24 \mathrm{~h}$ after drug administration. In a second group of animals, CCI surgery and behavioral measures were conducted as described above. At 10-14 d after surgery, ATL313 $(1 \mu \mathrm{M})$ was administered intrathecally. One week after ATL313 administration, ZM21385 $(10 \mu \mathrm{M})$ or equivolume vehicle $(1 \mu \mathrm{l})$ was administered intrathecally. Behavioral responses were measured $24 \mathrm{~h}$ after ATL313 administration, before ZM241385 and 1, 2, 3, 4, 6, and $24 \mathrm{~h}$ after drug administration.

Experiment 3: effect of repeated dosing of an $A_{2 A} R$ agonist on CCI allodynia. CCI surgery and behavioral measures were conducted as described in experiment 1 . At 10-14 d after surgery, a single intrathecal injection of ATL313 $(1 \mu \mathrm{M})$ or equivolume vehicle was administered. The rats then received additional injections, the same as that received on the first injection, once every 4 weeks after the first injection for a total of three injections. The behavioral testing was conducted before surgery, before each injection, $24 \mathrm{~h}$ after each injection, and weekly thereafter for 14 weeks after the first injection ( $n=6 /$ CCI group and $n=6 /$ sham group).

Experiment 4: effect of opioid antagonists on the $A_{2 A} R$ agonist-mediated reversal of CCI-allodynia. As previous reports have implicated endogenous opioids in some $\mathrm{A}_{2 \mathrm{~A}} \mathrm{R}$-mediated effects at supraspinal sites (Schiffmann et al., 2007), a mixture of selective opioid receptor antagonists was used to explore whether endogenous opioids account for the reversal of CCIinduced allodynia by ATL313. CCI surgery and behavioral measures were conducted as described in experiment 2 . At 10-14 d after surgery, ATL313 $(1 \mu \mathrm{M})$ was administered intrathecally. Once the CCI-induced mechanical allodynia was stably reversed by ATL313, a combination of selective opioid receptor antagonists: $\mu$ (naloxonazine; $1 \mu \mathrm{M}$ in $1 \mu \mathrm{l}), \kappa$ (nor-binaltrophimine; $1 \mu \mathrm{M}$ in $1 \mu \mathrm{l}$ ), and $\delta$ (naltrindole; $1 \mu \mathrm{M}$ in $1 \mu \mathrm{l}$ ) or equivolume vehicle ( $3 \mu \mathrm{l}$ ) was administered intrathecally ( $n=6 /$ group). These doses were chosen to ensure adequate treatment, as they are each 10 -fold higher than those known to be effective in abolishing the effects of the opioid agonists in vivo (Lu et al., 2004; Nielsen et al., 2007). Behav- 
ioral responses were measured $24 \mathrm{~h}$ after ATL313 administration, before opioid antagonist/vehicle administration and $0.5,1,2$, and $3 \mathrm{~h}$ after drug administration.

Experiment 5: effect of neutralizing IL-10 antibody on the $A_{2 A} R$ agonist effect in CCI allodynia. Chronic constriction injury was conducted and behavioral responses to mechanical stimuli were tested as described in experiment 2. At 10-14 d after surgery, an acute intrathecal administration of ATL313 $(1 \mu \mathrm{M})$ or equivolume vehicle $(1 \mu \mathrm{l})$ was coadministered with either sheep anti-rat neutralizing IL-10 IgG antibodies $(0.2 \mu \mathrm{g} / \mathrm{ml}$; $10 \mu \mathrm{l})$ or equivolume and equidose sheep $\operatorname{IgG}(0.2 \mu \mathrm{g} / \mathrm{ml} ; 10 \mu \mathrm{l})$ was coadministered ( $n=6$ rats per group). Behavioral responses were measured 3, 6, 24, $48 \mathrm{~h}$, and 1 week after drug administration. A second injection of sheep anti-rat neutralizing IL-10 IgG antibodies $(0.2 \mu \mathrm{g} / \mathrm{ml}$; $10 \mu \mathrm{l}$ ) or equivolume and equidose sheep IgG was injected intrathecally 1 week later, and behavioral responses to mechanical stimuli were measured before drug administration and 1, 2, 3, 4, 6, 24, $48 \mathrm{~h}$, and 1 week after drug administration.

Experiment 6: effect of $A_{2 A} R$ agonist on glial activation markers in the lumbar spinal cord. Groups of rats received either CCI or sham surgery, followed 10-14 d after surgery with either ATL313 ( $1 \mu \mathrm{M})$ or equivolume vehicle intrathecally. One week and 4 weeks after drug administration, the animals were injected intraperitoneally with a terminal dose of sodium pentobarbital ( $n=3-4$ /group). Animals were transcardially perfused with ice-cold heparinized saline followed by $4 \%$ paraformaldehyde/0.1 M PBS. Lumbar spinal cord sections were dissected and postfixed overnight in $4 \%$ paraformaldehyde. The lumbar spinal cord was cryoprotected in 30\% sucrose solution and processed for microglial and astrocytes activation using immunohistochemistry.

Experiment 7: effect of $A_{2 A} R$ agonist on gene expression. Groups of animals ( $n=8-10$ /group) received either CCI or sham surgery, followed $10-14 \mathrm{~d}$ after surgery with either ATL313 $(1 \mu \mathrm{M})$ or equivolume vehicle intrathecally. One week after drug administration, rats were deeply anesthetized with sodium pentobarbital (intraperitoneal injection, $0.8 \mathrm{ml}$ ). CSF was aspirated via acute lumbar technique as described for the acute lumbar intrathecal injections. The CSF was centrifuged at $1000 \times g$ for 10 min at $4^{\circ} \mathrm{C}$ to pellet the cells. The CSF cells were processed into cDNA as described above. Animals were then transcardially perfused with ice-cold saline for $2 \mathrm{~min}$. The lumbar spinal cord (L4-L6 region) was dissected out. The meninges and lumbar tissue were processed together for gene expression. In a separate group of animals, the overlying meninges were separated from the spinal tissue and processed for gene expression. The CSF was collected on both groups of animals for mRNA analysis. All tissues were flash frozen in liquid nitrogen and stored at $-80^{\circ} \mathrm{C}$ until additional analysis.

\section{Results}

Experiment 1: effect of $A_{2 A} R$ agonists on peripheral neuropathy-induced mechanical allodynia and thermal hyperalgesia

We examined the effects of two structurally different $\mathrm{A}_{2 \mathrm{~A}} \mathrm{R}$ agonists on CCI-induced mechanical allodynia to identify whether intrathecal administration of $\mathrm{A}_{2 \mathrm{~A}} \mathrm{R}$ agonists produces comparable results with that observed in vitro (Hasko et al., 1996). Figure 1 shows that the mechanical allodynia induced after CCI surgery remains stable from $10 \mathrm{~d}$ throughout the duration of the study $(8$ weeks after surgery). A single bolus dose of ATL313 (1 $\mu \mathrm{M})$, administered intrathecally between 10 and $14 \mathrm{~d}$ after surgery, induced a significant attenuation of the mechanical allodynia induced by CCI surgery for 4 weeks in both the ipsilateral and contralateral hindpaw $\left(p<0.01\right.$; interaction, $F_{(9,160)}=2.176$; $n=6-7$ /group). Sham surgery had no significant impact on behavior throughout the study. Additionally, ATL313 $(1 \mu \mathrm{M})$ had no significant effect on behavioral responses of sham-operated rats $(p>0.05)$ (Fig. 1). The lower dose of ATL313 (0.1 $\mu \mathrm{M})$ administered to allodynic rats had no significant effect on the mechanical allodynia at any time tested $(p>0.05$; main effect of drug, $\left.F_{(1,9)}=0.025\right)$ (Fig. 1).

\section{A Ipsilateral hindpaw}

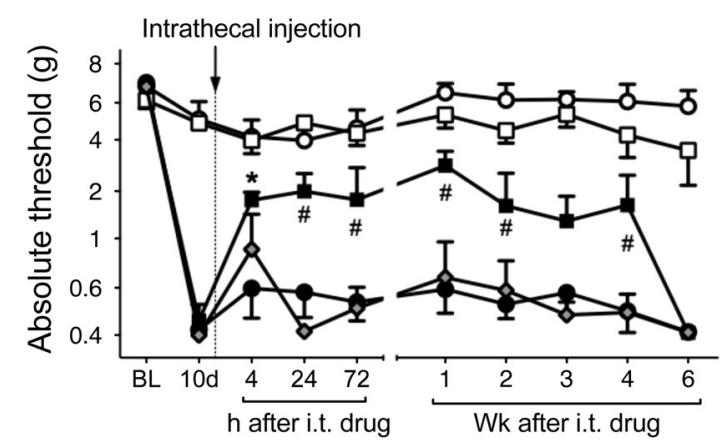

Time

\section{vehicle ATL313 $(1 \mu \mathrm{M}) \diamond \operatorname{ATL313}(0.1 \mu \mathrm{M})$ O Sham+vehicle $\square$ Sham+ATL313 $(1 \mu \mathrm{M})$}

\section{B Contralateral hindpaw}

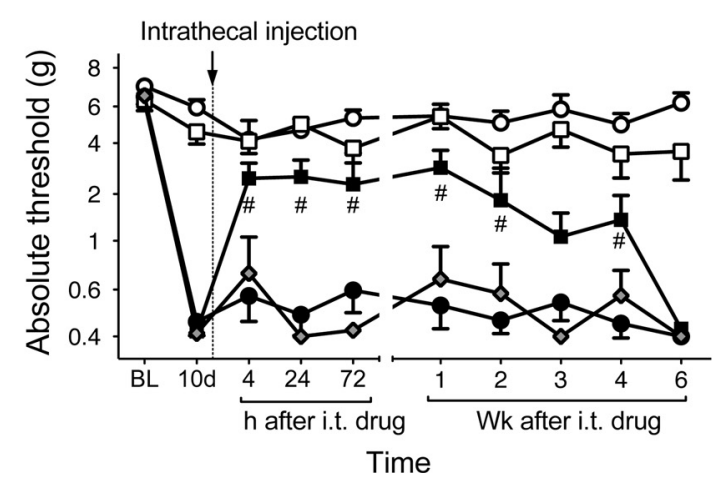

Figure 1. Mechanical allodynia is induced by $\mathrm{CCl}$ surgery but not in sham-operated animals. Mechanical thresholds were as assessed by von Frey testing. Intrathecal $A_{2 A}$ agonist, ATL313 ( $A_{2 A} R$ agonist), given 10-14 d after $C(\mathrm{Cl}$ surgery, reverses $C(\mathrm{Cl}$-induced mechanical allodynia for 4 weeks after administration (solid squares) in both the ipsilateral hindpaw $(\boldsymbol{A})$ and contralateral hindpaw $(\boldsymbol{B})$ (main effect of drug, $F_{(3,19)}=47.45, p<0.0001$; main effect of time, $F_{(7,133)}=2.68, p=0.013$; interaction, $F_{(21,133)}=2.176, p=0.004 ; n=$ $6-7$ /group). ATL313 has no effect on sham-operated animals. ATL313 reverses bilateral C(Iinduced allodynia at $1 \mu \mathrm{m}$ but has no effect at $0.1 \mu \mathrm{m}$ on either the ipsilateral $(\boldsymbol{A})$ or contralateral $(\boldsymbol{B})$ hindpaw (main effect of drug, $F_{(3,20)}=336.4, p<0.0001$; main effect of time, $F_{(9,200)}=$ $11.68, p<0.0001$; interaction, $\left.F_{(27,200)}=11.04, p<0.0001\right)$. Data are presented as mean \pm SEM. Solid squares, CCI plus ATL313 (1 $\mu \mathrm{M})$; gray diamond, CCI plus ATL313 $(0.1 \mu \mathrm{M})$; solid circles, CCI plus vehicle; open squares, sham plus ATL313 $(1 \mu \mathrm{M})$; open circles, sham plus vehicle. ${ }^{*} p<$ $0.05, " \#<0.01$, drug against vehicle at the respective time point.

Based on these results, the effect of $1 \mu \mathrm{M}$ ATL313 was tested for its effects on CCI-induced thermal hyperalgesia (Fig. 2). Comparable results were obtained against thermal hyperalgesia as that against mechanical allodynia; that is, ATL313 significantly reversed CCI-induced thermal hyperalgesia for $4+$ weeks, with no effect of the drug on the responses of sham controls $(p<$ 0.0001 ; interaction, $F_{(27,200)}=11.04 ; n=6$ /group).

To begin to provide converging lines of evidence that $A_{2 A} R$ agonism underlies the effects observed above, a second, structurally distinct $\mathrm{A}_{2 \mathrm{~A}} \mathrm{R}$ agonist, CGS21680, was also tested and found to produce the same effect as that of ATL313 in allodynic rats at a 10 -fold higher dose $(p<0.001$; interaction, $F_{(9,160)}=2.865 ; n=6 /$ group) (Fig. 3 ), which is consistent with their relative receptor binding affinities. Therefore, both ATL313 and CGS21680 produced a reduction of neuropathicinduced allodynia for $4+$ weeks after a single intrathecal administration. 


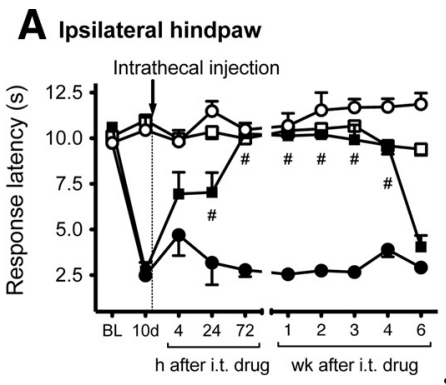

B Contralateral hindpaw
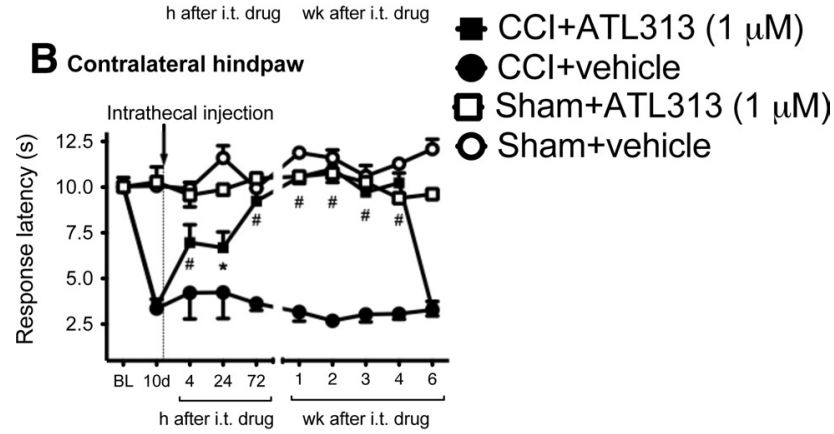

C Tail

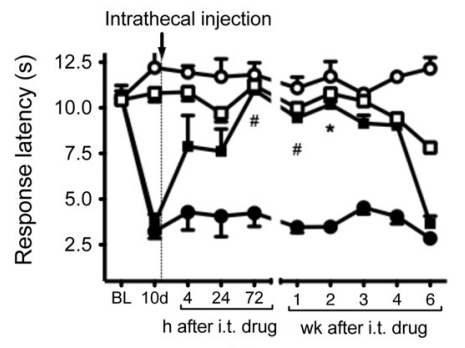

Time

Figure 2. Intrathecal $A_{2 A} R$ agonist, ATL313 $(1 \mu \mathrm{M})$, given 10-14 d after CCl surgery, reverses $\mathrm{CCl}$-induced thermal allodynia for 4 weeks after administration in both the ipsilateral hindpaw $(\boldsymbol{A})$, contralateral hindpaw $(\boldsymbol{B})$, and tail $(\boldsymbol{C})$. ATL313 has no effect on sham-operated animals (main effect of drug, $F_{(3,20)}=336.4, p<0.0001$; main effect of time, $F_{(9,200)}=11.68, p<0.0001$; interaction, $F_{(27,200)}=11.04, p<0.0001 ; n=6$ per group). We assessed thermal thresholds by modified Hargreaves. Data are presented as mean \pm SEM. Solid squares, CCI plus ATL313 $(1 \mu \mathrm{m})$; solid circles, CCI plus vehicle; open squares, sham plus ATL313 (1 $1 \mu \mathrm{M})$; open circles, sham plus vehicle. ${ }^{*} p<0.05,{ }^{\sharp} p<0.01$, drug against vehicle at the respective time point.

Experiment 2: effect of $A_{2 A} R$ blockade on the $A_{2 A} R$ agonist effect

As a second test to validate that the effect of ATL313 is indeed $A_{2 A} R$ mediated, a single intrathecal injection of an $A_{2 A} R$ selective antagonist (ZM23185) was coadministered with a single intrathecal injection of ATL313 10-14 d after CCI surgery. Coadministration of the $\mathrm{A}_{2 \mathrm{~A}} \mathrm{R}$ agonist (ATL313) and $\mathrm{A}_{2 \mathrm{~A}} \mathrm{R}$ antagonist (ZM23185; $10 \mu \mathrm{M}$ ) abolished the effect of the $\mathrm{A}_{2 \mathrm{~A}} \mathrm{R}$ agonist alone in reversing neuropathic-induced allodynia (Fig. $4 A)(p<0.001$; interaction, $F_{(6,93)}=12.67 ; n=6$ /group). The $\mathrm{A}_{2 \mathrm{~A}} \mathrm{R}$ antagonist (ZM23185) administered alone produced no effect on CCIinduced allodynia $(p>0.05)$. Therefore, the initiation of the effect of an $\mathrm{A}_{2 \mathrm{~A}} \mathrm{R}$ agonist on neuropathic pain is mediated by $A_{2 A}$ Rs. To assess whether the sustained effect is also mediated by $\mathrm{A}_{2 \mathrm{~A}} \mathrm{R}$, we administered the $\mathrm{A}_{2 \mathrm{~A}} \mathrm{R}$ antagonist 1 week after the administration of the $A_{2 A} R$ agonist (ATL313). There was no significant effect of the $\mathrm{A}_{2 \mathrm{~A}} \mathrm{R}$ antagonist, ZM23185, on the established ATL313-induced reversal of CCI-induced allodynia ( $p=0.76$; main effect of drug, $F_{(1,9)}=0.696 ; n=6$ /group) (Fig. $4 B$ ).

\section{A Ipsilateral hindpaw}

Intrathecal injection

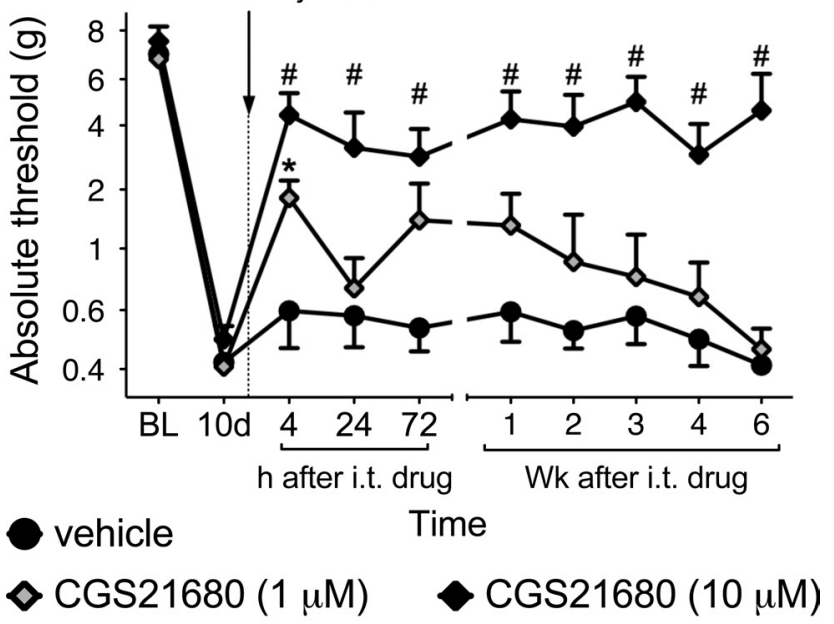

\section{B Contralateral hindpaw}

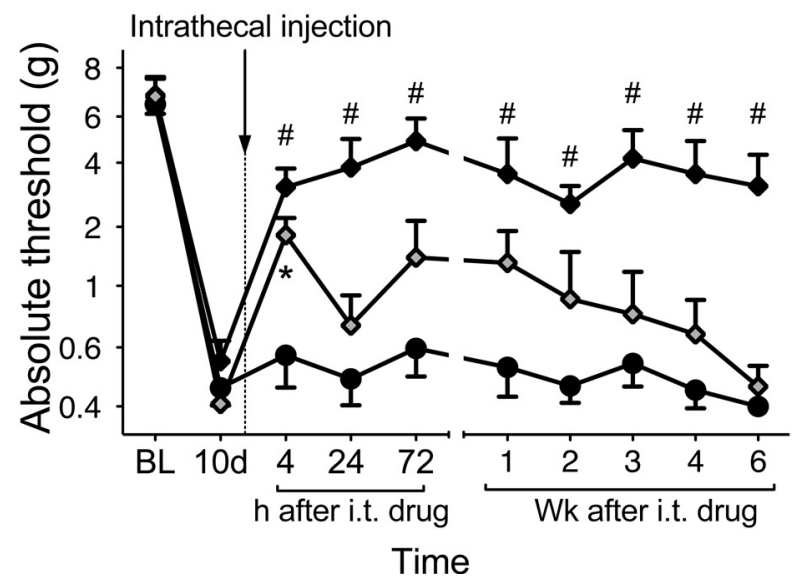

Figure 3. CGS21680 (10 or $1 \mu \mathrm{m}$ in $1 \mu \mathrm{l})$, another $\mathrm{A}_{2 \mathrm{~A}}$ agonist, dose-dependently reverses CCl-induced mechanical allodynia (assessed by von Frey filaments) in both the ipsilateral $(\boldsymbol{A})$ and contralateral $(\boldsymbol{B})$ hindpaw but requires a 10-fold higher dose than ATL313 in C Cl-induced allodynic animals to produce the same 4 week reversal of allodynia (main effect of drug, $F_{(2,9)}=$ 93.03, $p<0.0001$; main effect of time, $F_{(9,160)}=23.19, p<0.0001$; interaction, $F_{(18,160)}=$ $2.87, p<0.01 ; n=6$ per group). Data are presented as mean \pm SEM. Solid diamonds, CCI plus CGS21680 (10 $\mu \mathrm{m})$; gray diamonds, CCI plus CGS21680 (1 $\mu \mathrm{m})$; solid circles, CCI plus vehicle. ${ }^{*} p<0.05,{ }^{\#} p<0.01$, drug against vehicle at the respective time point.

Experiment 3: effect of repeated dosing of an $A_{2 A} R$ agonist on CCI allodynia

To assess whether tolerance to the $\mathrm{A}_{2 \mathrm{~A}} \mathrm{R}$ agonist would occur with repeated dosing, we gave the $\mathrm{A}_{2 \mathrm{~A}} \mathrm{R}$ agonist once every 4 weeks, when the drug effect was still apparent (Fig. 5). The rats did not develop tolerance to ATL313 when given once every 4 weeks as the reversal of allodynia was maintained for 11 weeks after the first injection, compared with CCI plus vehicle $(p<0.0001$; interaction, $F_{(39,260)}=6.439 ; n=6$ /group). The reversal of allodynia may have lasted longer except that the allodynia induced by the CCI was resolving by 11 weeks after intrathecal injection.

Experiment 4: effect of opioid antagonists on the $A_{2 A} R$ agonist-mediated reversal of CCI allodynia

Given the interaction between adenosine receptors and opioid receptors, we assessed whether the long-term reduction in allodynia after ATL313 administration in neuropathic rats was opioid receptor mediated. To ensure that we blocked all opioid 
A Co-administration of agonist and antagonist

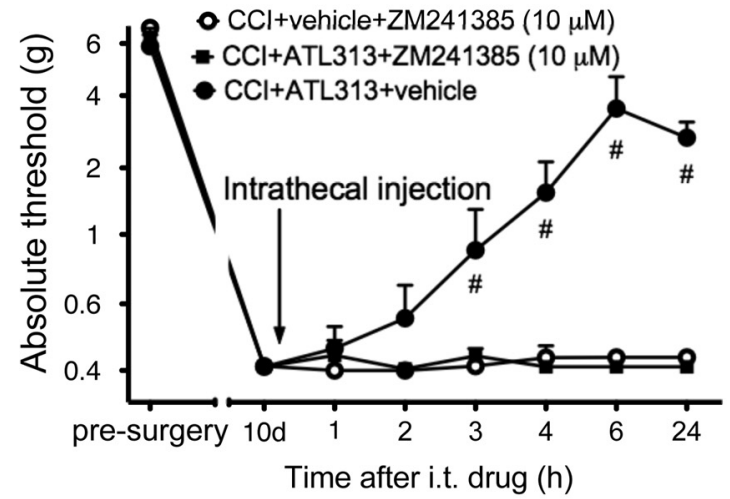

B Delayed administration of antagonist after agonist

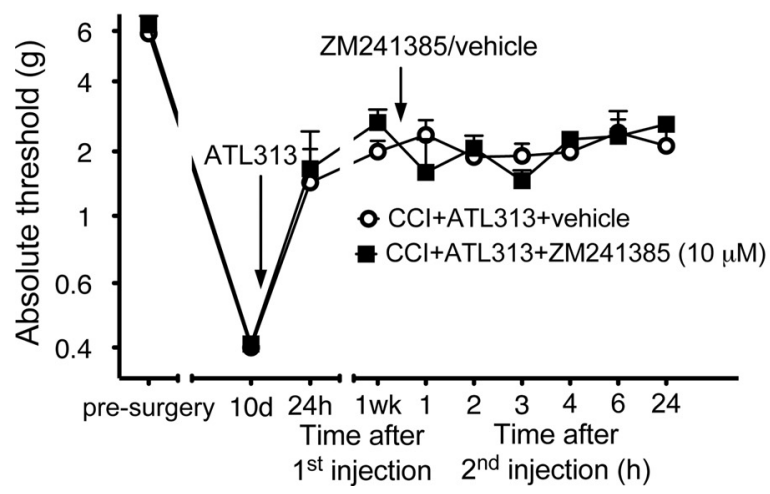

Figure 4. An $A_{2 A}$ agonist $(1 \mu \mathrm{M})$ coadministered with an $A_{2 A} R$ selective antagonist (ZM23185; $10 \mu \mathrm{M}$ ) completely abolished the effect of the $A_{2 A} R$ agonist in CCl-induced allodynic animals $(\boldsymbol{A})$ (main effect of drug, $p<0.0001, F_{(2,6)}=110.3$; main effect of time, $p<0.0001$, $F_{(6,93)}=13.49$; interaction, $p<0.0001, F_{(12,93)}=12.67 ; n=6$ per group). When the antagonist (ZM23185; $10 \mu \mathrm{M})$ was administered 1 week after the administration of the $A_{2 A}$ agonist (ATL313; $1 \mu \mathrm{M})$, in allodynic animals, there was no significant effect of the antagonist on the animals reversed by the agonist $(\boldsymbol{B})$ (main effect of drug, $p=0.696, F_{(1,9)}=0.153 ; n=6$ per group). Data are presented as mean \pm SEM. Solid circles, CCI plus ATL313 plus vehicle; open circles, CCl plus vehicle plus ZM23185; solid squares, CCI plus ATL313 plus ZM231865. ${ }^{\#} p<$ 0.01, ATL313 plus antagonist against ATL313 plus vehicle at the respective time point.

receptors effectively, we used a 10-fold higher dose than that used previously and used antagonists for $\mu, \kappa$, and $\delta$ opioid receptors. After intrathecal ATL313 stably reversed CCI-induced mechanical allodynia for 1 week, a combination of $\kappa(1 \mu \mathrm{M}$ nor-binaltrophimine), $\delta$ (1 $\mu \mathrm{M}$ naltrindole), and $\mu$ (1 $\mu \mathrm{M}$ naloxonazine $)$ opioid receptor antagonists were coadministered intrathecally. Before administration of the opioid antagonists or vehicle, there was no significant difference between the groups (Fig. 6). After the administration of the opioid antagonists, there was no significant effect of the opioid antagonists on the $\mathrm{A}_{2 \mathrm{~A}} \mathrm{R}$-mediated reversal of neuropathic allodynia compared with vehicle injections $\left(p=0.73\right.$; main effect of drug, $F_{(1,7)}=0.120 ; n=6$ per group). Therefore, although we have not tested in involvement of opioids in the onset of the $A_{2 A} R$ drug effect, the sustained $A_{2 A} R$ reversal of mechanical allodynia does not appear to involve endogenous opioids.

Experiment 5: effect of neutralizing IL-10 antibody on the $\mathrm{A}_{2 \mathrm{~A}} \mathrm{R}$ agonist effect in CCI allodynia

Previous studies of $\mathrm{A}_{2 \mathrm{~A}} \mathrm{R}$ effects on peripheral immune cells have implicated increased release of IL-10 as importantly contributing to the anti-inflammatory effects of $\mathrm{A}_{2 \mathrm{~A}} \mathrm{R}$ agonists (Hasko et al.,

\section{A Ipsilateral hind paw}
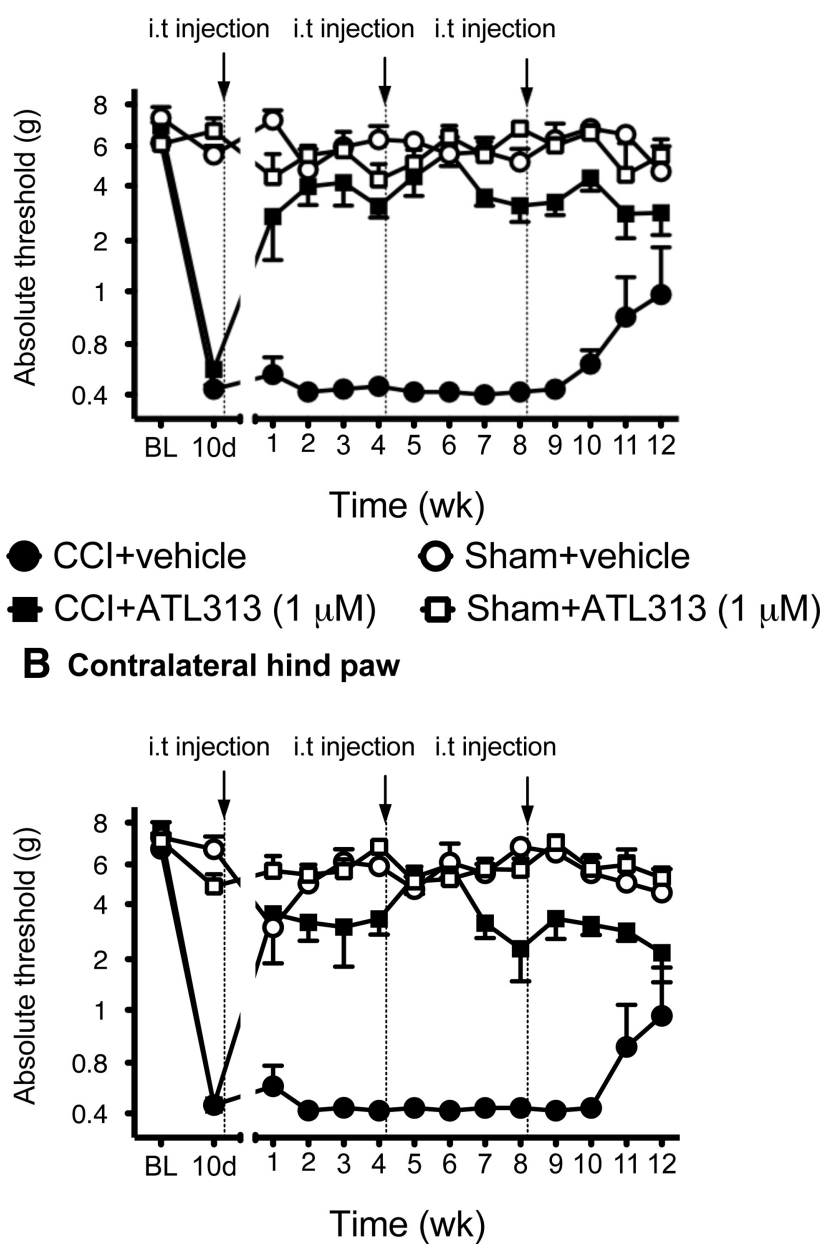

Figure 5. An $A_{2 A}$ R agonist (ATL3131 $\mu \mathrm{m}$ ) intrathecally administered every 4 weeks (total, 3 injections) in rats with (Cl-induced allodynia is able to sustain the reversal of allodynia for at least 12 weeks (data ongoing), as measured by von Frey testing in both the ipsilateral hindpaw $(\boldsymbol{A})$ and contralateral hindpaw $(\boldsymbol{B})$. The first injection was administered $10 \mathrm{~d}$ after $\mathrm{CCl}$ or sham surgery (main effect of drug, $F_{(3,20)}=239.9, p<0.0001$; main effect of time, $F_{(13,260)}=10.69$, $p<0.0001$; interaction, $F_{(39,260)}=6.349, p<0.0001 ; n=6$ per group). Data are presented as mean \pm SEM. Solid squares, CCI plus ATL313 $(1 \mu \mathrm{m})$; solid circles, CCI plus vehicle; open squares, sham plus ATL313 (1 $\mu \mathrm{M})$; open circles, sham plus vehicle.

1996; Csoka et al., 2007b). No previous studies have explored whether IL-10 may be involved in $A_{2 A} R$ effects centrally. Therefore, we assessed whether neutralizing IL-10 in the intrathecal space, using IL-10 antibodies, would abolish the effect of the $\mathrm{A}_{2 \mathrm{~A}} \mathrm{R}$ agonist. After establishment of CCI-induced mechanical allodynia, we administered intrathecal ATL313 together with neutralizing IL-10 IgG versus control IgG (Fig. 7). There was no significant effect of the IL-10 antibodies when coadministered with the ATL313, suggesting that the initial effect of the $A_{2 A} R$ agonist is not via IL-10 ( $p=0.314$; main effect of drug, $F_{(3,20)}=$ 1.263). One week after the first intrathecal injection, the rats were injected with a second dose each of either neutralizing IL-10 IgG or control IgG, according to the same grouping as the first injection. Now, neutralizing IL-10 reversed the enduring effect of the $\mathrm{A}_{2 \mathrm{~A}} \mathrm{R}$ agonist $\left(p<0.05\right.$; main effect of drug, $F_{(3,20)}=4.001 ; n=$ 6 per group). Interestingly, the effect of the $A_{2 A} R$ agonist returned by $48 \mathrm{~h}$ after the neutralizing IL-10 antibodies had been administered, suggesting that the $\mathrm{A}_{2 \mathrm{~A}} \mathrm{R}$ agonist induces sustained release of IL-10 contributing to the long-lasting effect of the drug. 


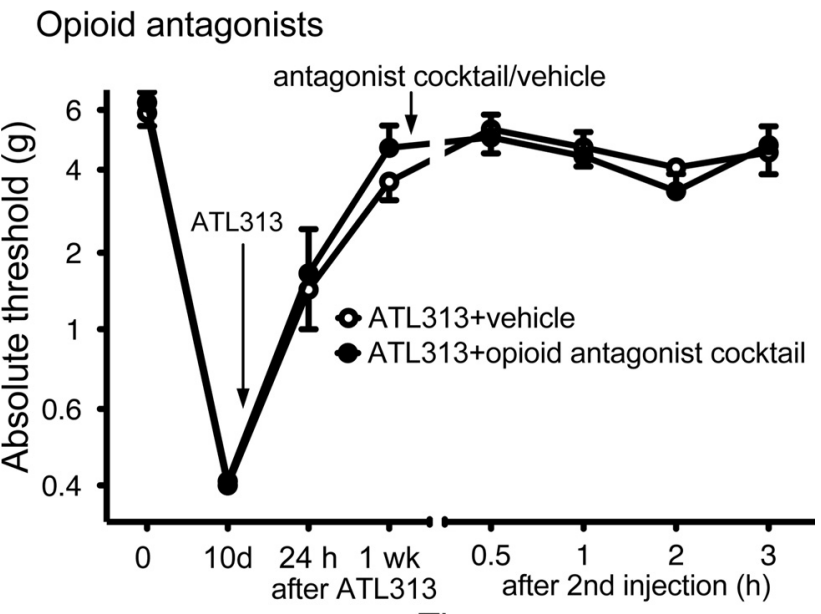

Time

Figure 6. The effect of ATL313 in reversing CCl-induced mechanical allodynia is not mediated by opioid receptors as assessed by von Frey testing. ATL313 (1 $\mu \mathrm{m}$ in $1 \mu \mathrm{l})$ was administered intrathecally $10-14 \mathrm{~d}$ after $\mathrm{CCl}$ surgery. Once the neuropathic pain was stably reversed by ATL313 (at least 1 week), a combination of opioid antagonists selective for $\kappa(1 \mu \mathrm{m}$ norbinaltorphimine), $\delta$ (1 $\mu$ m naltrindole), and $\mu$ (1 $\mu$ m naloxonazine) had no effect on established reversal of CCl-induced allodynia by ATL313 measured $30 \mathrm{~min}, 1,2$, and $3 \mathrm{~h}$ after drug administration ( $1 \mu \mathrm{m}$; main effect of drug, $F_{(1,7)}=0.120, p=0.731 ; n=6$ per group). Data are presented as mean \pm SEM. Solid circle, CCl plus ATL plus opioid antagonist mixture; open circle, CCI plus ATL plus vehicle.

However, given the rats received the IL-10 neutralizing antibodies in both the first and second injection, it is not certain whether the first injection of IL-10 neutralizing antibody may have potentially impacted the effect of the second.

\section{Experiment 6: effect of $A_{2 A} R$ agonist on glial activation} markers in the lumbar spinal cord

Previous studies of peripheral immune cells have documented that $\mathrm{A}_{2 \mathrm{~A}} \mathrm{R}$ agonists can suppress the expression of activation markers on monocytes/macrophages (Mantovani et al., 2002; Kreckler et al., 2006; Hasko et al., 2007). No previous studies have explored whether similar effects could be produced centrally. Therefore, we assessed the effect of ATL313 on the predominant immunocompetent cells within the CNS by measuring immunohistochemical indices of glial activation, known to occur in spinal cord dorsal horn, in both the ipsilateral and contralateral sides, in response to CCI (Figs. 8, 9). On the ipsilateral side, microglial activation (measured by OX-42 labeling) in CCI rats was significantly lower 1 week $\left(p<0.001 ; F_{(3,9)}=14.85\right)$ and 4 weeks $(p<$ $\left.0.01 ; F_{(3,9)}=7.37\right)$ after a single intrathecal dose of ATL313, compared with rats receiving CCI plus vehicle, sham surgery plus vehicle, or sham surgery plus ATL313. In addition, there was a significant attenuation of the astrocyte activation marker, GFAP, on the ipsilateral side, in CCI rats at 1 week $\left(p<0.01 ; F_{(3,11)}=\right.$ $8.32)$ and 4 weeks $\left(p<0.05 ; F_{(3,12)}=4.14\right)$ after a single intrathecal dose of ATL313, compared with rats receiving CCI plus vehicle. On the contralateral side, there was no significant differences in microglial activation markers between any of the groups at either 1 or 4 weeks after drug administration $\left(F_{(3,8)}=2.090\right.$; $p=0.18)$. Astrocyte activation marker, GFAP, was significantly increased in the contralateral dorsal horn after CCI surgery compared with sham plus ATL313 at 1 week $(p<0.05)$ and both sham controls at 4 weeks $(p<0.05)$. The increase in astrocytes activation observed in CCI was significantly attenuated after administration of ATL313 at both 1 week $\left(p<0.001 ; F_{(3,11)}=\right.$ $13.96)$ and 4 weeks $\left(p<0.01 ; F_{(3,10)}=10.28\right)$.

\section{A Ipsilateral hindpaw}

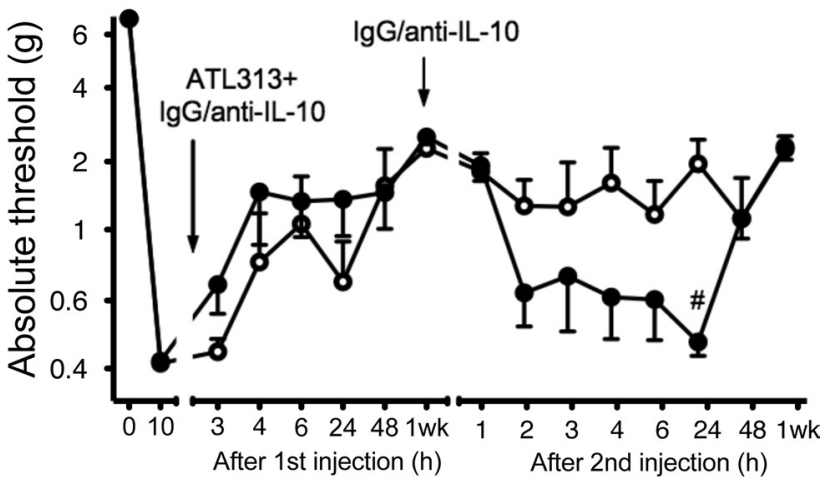

Time

\section{B Contralateral hindpaw}

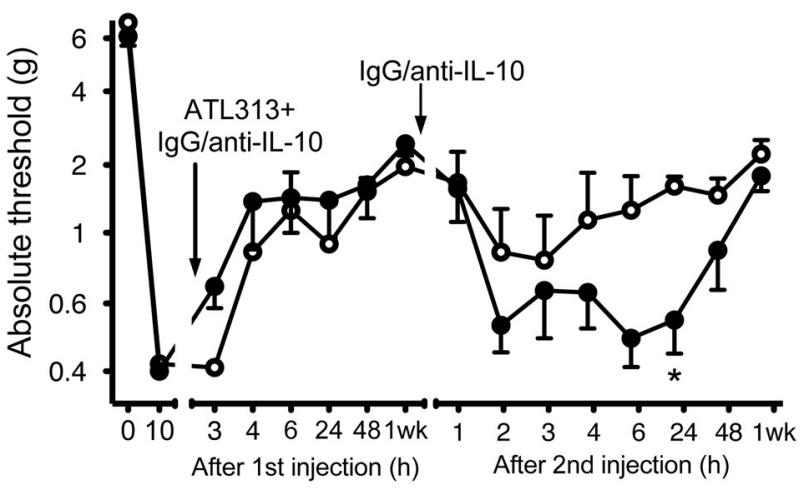

Time

Figure 7. Ten to $14 \mathrm{~d}$ after $\mathrm{CCl}$, ATL313 $(1 \mu \mathrm{M})$ was coadministered intrathecally with either IL-10 neutralizing antibodies $(0.2 \mu \mathrm{g}$ in $10 \mu \mathrm{l})$ or equivolume lgG. The behavioral response to mechanical stimuli, assessed by von Frey testing, was measured before surgery, before drug administration, and after drug administration in the ipsilateral $(\boldsymbol{A})$ and contralateral $(\boldsymbol{B})$ hindpaw. No significant effect was found when the drugs were coadministered (main effect of drug, $\left.p=0.31, F_{(3,20)}=1.263\right)$. Allowing 1 week washout, a second injection of the IL-10 neutralizing antibodies $(0.2 \mu \mathrm{g}$ in $10 \mu \mathrm{l})$ or equivolume lgG was administered. The IL-10 neutralizing antibodies reversed the effect of ATL313 at $24 \mathrm{~h}$ but had returned within $48 \mathrm{~h}$ to that comparable before neutralizing antibody administration (main effect of drug, $p<0.05, F_{(1,8)}=6.339$; main effect of time, $p<0.0001, F_{(8,80)}=5.921$; interaction, $p<0.001, F_{(8,80)}=2.975 ; n=$ 6 per group). Data are presented as mean \pm SEM. Solid circle, CCI plus ATL plus IL-10 neutralizing antibodies; open circle, CCI plus ATL plus IgG vehicle. ${ }^{*} p<0.05,{ }^{\#} p<0.01$ antagonist against vehicle at the respective time point.

Experiment 7: effect of $A_{2 A} R$ agonist on gene expression Previous studies of peripheral immune cells have documented that $\mathrm{A}_{2 \mathrm{~A}}$ agonists can increase $I L-10$ gene expression and suppress the proinflammatory cytokine TNF- $\alpha$ gene expression in monocytes/macrophages (Hasko et al., 1996; Csoka et al., 2007a). No previous studies have explored whether similar effects could be produced centrally. Here, tissues (CSF cells, L4-L6 lumbar spinal cord with overlying meninges, or meninges alone; $n=6-8$ / group) were collected after stable reversal of CCI-induced mechanical allodynia by ATL313. As shown in Figure 10, there was a significant increase in $I L-10$ gene expression in cells within the CSF (two-way ANOVA with surgery and drug as main effects, drug effect: $\left.p<0.05, F_{(1,22)}=159.5\right)$. There was no significant difference in $I L-10 \mathrm{mRNA}$ in the meninges between groups (drug effect: $\left.p=0.33, F_{(1,22)}=0.976\right)$ or in the lumbar tissue with the 

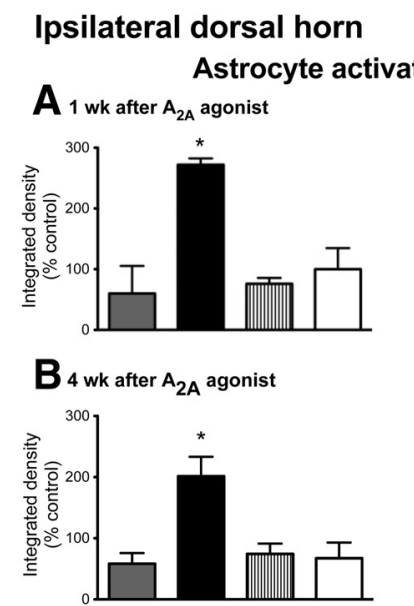

\section{Contralateral dorsal horn on marker (GFAP)}
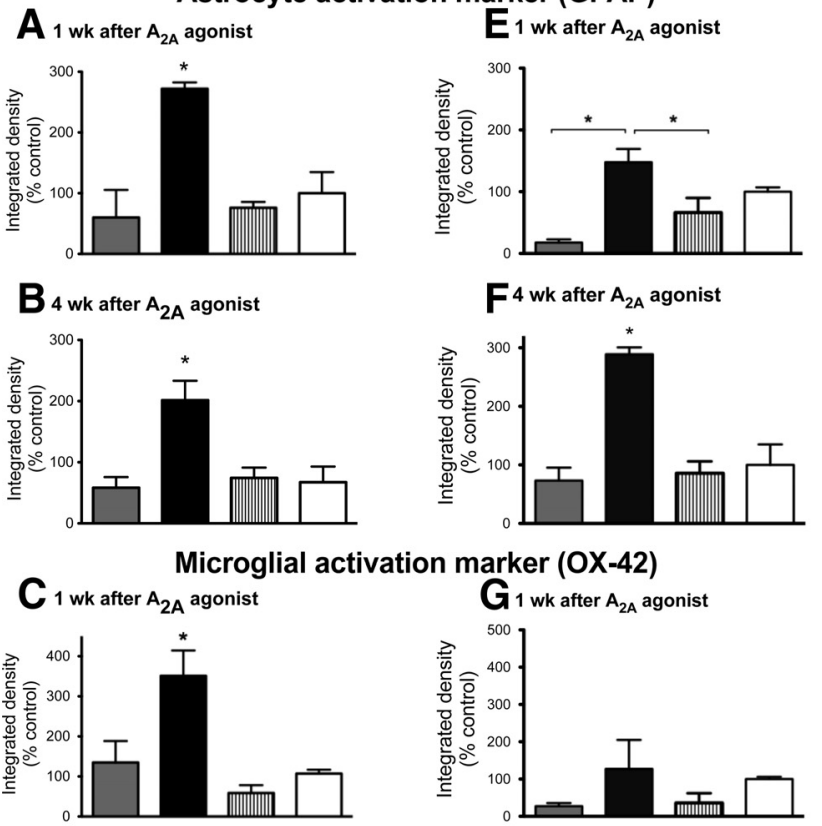

$D_{4}$ wk after $A_{2 A}$ agonist

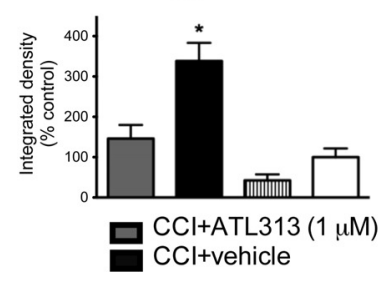

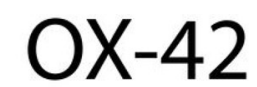

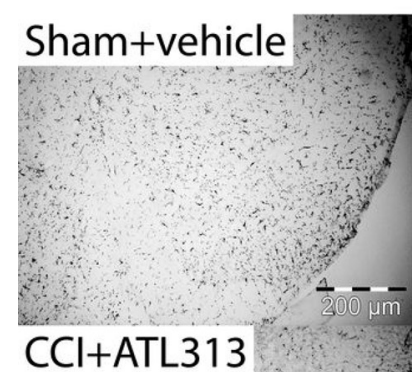

Sham+vehicle

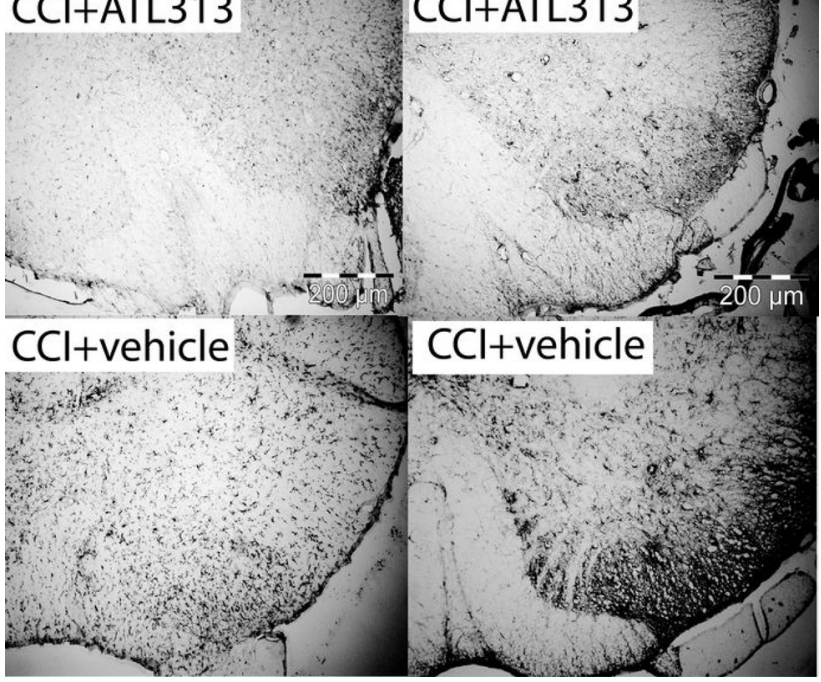

Figure 9. Representative photomicrographs of immunoreactivity of OX-42 and GFAP (10X magnification) are shown displaying the ipsilateral dorsal horn of the lumbar $L 4-L 6$ region at 1 week after intrathecal injection. The insets show the morphological changes of the microglia (OX-42) and astrocytes (GFAP) in the CCl rats. The activation of these glia is attenuated after intrathecal administration of an $A_{2 A}$ receptor agonist (ATL313) such that the morphology is closer to the sham-operated animals.

precedented, enduring reversal occurred for both mechanical allodynia and thermal hyperalgesia. The $\mathrm{A}_{2 \mathrm{~A}} \mathrm{R}$ agonist effects likely involve suppression of astrocyte and microglial activation based on activation marker analysis plus involvement of the antiinflammatory cytokine IL-10 in the pain suppression as IL-10 receptors are expressed by spinal glia, but not spinal neurons (Ledeboer et al., 2003). The effects are not unique to one $\mathrm{A}_{2 \mathrm{~A}} \mathrm{R}$ selective compound, as comparable results were obtained using two structurally distinct $\mathrm{A}_{2 \mathrm{~A}} \mathrm{R}$-selective agonists (ATL313 and CGS21680). Whether the increased potency of ATL313, relative to CGS21680, reflects differences in receptor affinity, tissue penetration, relative rates of degradation/clearance, or other differences is unknown. The $A_{2 A} R$ agonists are not analgesic, but rather antiallodynic/antihyperalgesic, as they have no effect on nonneuropathic animals. Furthermore, the long-duration $A_{2 A} R$ agonist effect in neuropathic rats is not opioid mediated, another positive feature for considering targeting $\mathrm{A}_{2 \mathrm{~A}} \mathrm{R}$ for pain control. The attenuation of neuropathic pain is mediated by $\mathrm{A}_{2 \mathrm{~A}} \mathrm{R}$ activation initially, but the sustained reversal of allodynia is likely mediated by IL-10 release, possibly from resident or recruited cells in the intrathecal space. The efficacy of $\mathrm{A}_{2 \mathrm{~A}} \mathrm{R}$-selective agonists in producing sustained reversal of neuropathic pain is not limited to the therapy being administered shortly $(10 \mathrm{~d})$ after neuropathic pain onset as equally potent, sustained reversal of neuropathic pain is observed when treatment is administered 6 weeks after CCI as well (Loram et al., 2009).

\section{Discussion}

This study documents that a single intrathecal bolus injection of $A_{2 A} R$ agonists reverse neuropathic pain for $4+$ weeks. This un- 


\section{Gene expression 1 wk after ATL313/vehicle injection}

\section{A IL-10 mRNA in CSF cells $\mathbf{B}$ IL-10 mRNA in lumbar tissue $\mathbf{C}$ IL-10 mRNA in meninges and meninges}
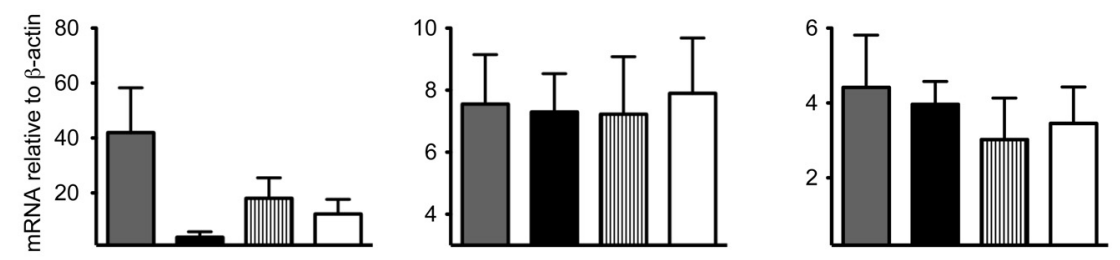

\section{TNF- $\alpha$ mRNA in CSF cells}
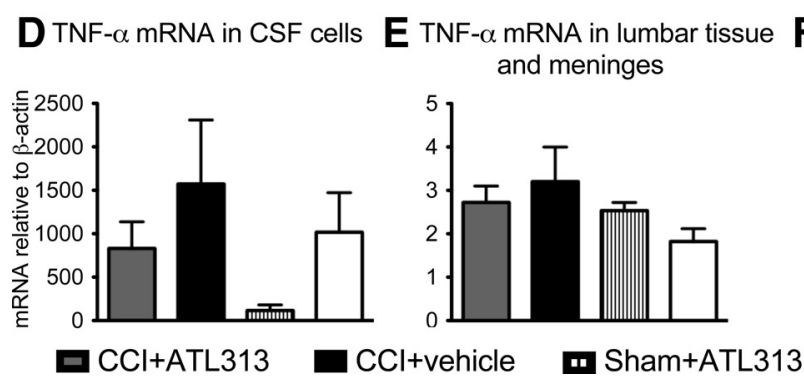

F TNF- $\alpha$ mRNA in meninges

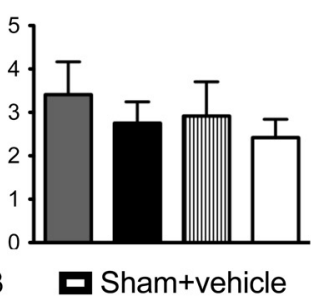

Figure 10. Gene expression mRNA expression in tissue collected 1 week after administration of ATL313 $(1 \mu \mathrm{m})$ or vehicle in CCI or sham-operated rats. Intrathecal drug administration was $10 \mathrm{~d}$ after CCI/sham surgery ( $n=7-10 /$ group). There was a significant elevation in IL-10 mRNA in CSF cells after ATL313 administration compared with vehicle controls (two-way ANOVA, drug effect, $p<0.05, F_{(1,21)}=4.604$; surgery effect, $\left.p=0.46, F_{(1,21)}=0.57\right)(A)$. There was no significant change in IL-10 mRNA in lumbar and meningial tissue (two-way ANOVA, drug effect, $p=0.898, F_{(1,21)}=0.017$; surgery effect, $\left.p=0.933, F_{(1,21)}=0.007\right)(B)$ or meninges alone (drug effect, $\left.p=0.332, F_{(1,21)}=0.976\right)(C)$. There was a significant increase in TNF- $\alpha$ mRNA in CSF cells after CCl plus vehicle compared with sham plus vehicle (CSF cells, $\left.p<0.05, F_{(1,21)}=3.792\right)$ (D) but not in CCI plus ATL313 versus CCI plus vehicle. There was no significant difference in TNF- $\alpha$ gene expression in the lumbar and meninges tissue between any of the groups (drug effect, $\left.p=0.832, F_{(1,21)}=0.046\right)(\boldsymbol{E})$ or in the meninges alone (drug effect, $\left.p=0.306, F_{(1,21)}=1.094\right)(\boldsymbol{F})$. Data are presented as mean \pm SEM and analyzed using ANOVA. Gray bar, CCI plus ATL313 $(1 \mu \mathrm{M})$; solid bar, CCl plus vehicle; vertical striped bar, sham plus ATL313 $(1 \mu \mathrm{m})$; white bar, sham plus vehicle. ${ }^{*} p<0.05$.

To date, only gene therapy produces longer than $\sim 1 \mathrm{~d}$ of pain relief from single injections. Even gene therapy is challenging in the intrathecal space, with single-dose viral vectors failing in efficacy by $\sim 2$ weeks (Milligan et al., 2005a,b) and repeated injections of optimized gene therapies required for more extended pain resolution. Given the difficulties of bringing intrathecal gene therapy to clinical trials, identifying novel drug approaches for extended pain relief may be ideal. Also, once-monthly intrathecal drugs that induce endogenous spinal IL-10 avoid potential peripheral immunosuppression inherent in daily systemic administration of glial activation inhibitors, as these may compromise the responses of peripheral immune cells as well (Watkins and Maier, 2003).

IL-10 gene therapy studies provide insights for the potential of single dose intrathecal $\mathrm{A}_{2 \mathrm{~A}} \mathrm{R}$ agonists for long-term pain control. Foremost is that no tolerance develops with extended IL-10 exposure for resolving thermal hyperalgesia and allodynia. Optimized IL-10 gene therapy provides $3+$ months of pain suppression, and when neuropathic pain does reoccur, an additional IL-10 gene therapy treatment again reverses neuropathic pain (Sloane et al., 2009b). Uncompromised pain reduction over extended time periods is recapitulated here, in which single intrathecal doses of ATL313 delivered once each month provided sustained, potent suppression of neuropathic pain. In addition, IL-10 gene therapy operates by driving IL- 10 production by cells within the CSF space, with IL-10 induced in this manner acting as a protracted intrathecal delivery of IL-10 to spinal cord glia, thereby suppressing pain (Sloane et al., 2009b). Upregulation of IL-10 in CSF cells appears likely to be recapitulated by single-dose intrathecal $\mathrm{A}_{2 \mathrm{~A}} \mathrm{R}$ agonists, suggestive that this may well contribute to both suppression of spinally mediated neuropathic pain and glial activation.

Previous studies report that $\mathrm{A}_{2 \mathrm{~A}} \mathrm{R}$ activation reduces neuroinflammatory symptoms in spinal cord injury, including motor deficits and markers of neuronal injury (Cassada et al., 2002; Reece et al., 2006). We have recently extended this to show that the $\mathrm{A}_{2 \mathrm{~A}} \mathrm{R}$ agonist, CGS21680, also potently suppresses paralysis in a rat model of multiple sclerosis (Loram et al., 2009). Thus, $A_{2 A} R$ agonism has far broader potential clinical utility than neuropathic pain.

No previous reports identified that $\mathrm{A}_{2 \mathrm{~A}} \mathrm{R}$ agonists elevate IL-10 in vivo, either peripherally or centrally, or that blocking IL-10 relieves symptoms, such as neuropathic pain. Unlike in vitro studies in which IL-10 is measured within $24 \mathrm{~h}$ after $24 \mathrm{~h}$ of constant $\mathrm{A}_{2 \mathrm{~A}} \mathrm{R}$ agonist exposure (Hasko et al., 1996; Kreckler et al., 2006; Csoka et al., 2007b), we have identified that the increase in IL-10 production is sustained in vivo after $\mathrm{A}_{2 \mathrm{~A}} \mathrm{R}$ agonist administration in neuropathic animals for $1+$ week but most likely 4 weeks given the duration of effect on neuropathic pain. Comparable with in vitro studies, it appears that an inflammatory stimulus is required, such as that seen after CCI surgery and subsequent neuropathy, in order for the $\mathrm{A}_{2 \mathrm{~A}} \mathrm{R}$ agonist to potentiate the IL-10 production. Although we did not identify a significant interaction between surgery and drug effect in the IL-10 mRNA, higher values were obtained in $\mathrm{A}_{2 \mathrm{~A}} \mathrm{R}$ agonist-treated neuropathic rats compared with vehicle-treated neuropathic animals.

Adenosine modulation may reduce neuropathic pain via activation of adenosine receptors either/or within spinal cord or resident or recruited immunocompetent cells within meninges or CSF (Ribeiro et al., 2002; Hasko and Cronstein, 2004; Dare et al., 2007). We have previously shown that meningeal cells can produce proinflammatory cytokines after activation both in vivo and in vitro (Wieseler-Frank et al., 2007). Also, CSF cells significantly increase after peripheral neuropathy and intrathecal IL-10 gene therapy, and IL-10 gene therapy shifts the cells from a predominantly ED1, or classically activated macrophage phenotype, to that of ED2, the alternatively activated or anti-inflammatory phenotype (Sloane et al., 2009b). Potentially, given increased IL-10 mRNA in CSF cells in response to $\mathrm{A}_{2 \mathrm{~A}} \mathrm{R}$ agonists, such drugs may alter the status of the cells recruited to, or resident within, the CSF and/or meninges into alternatively activated macrophages producing anti-inflammatory IL-10, especially under neuroinflammatory circumstances. The observed glial suppression may reflect $\mathrm{A}_{2 \mathrm{~A}} \mathrm{R}$ agonist diffusing into spinal tissue altering glial function. Alternatively, it is possible that downstream mediators produced within CSF after $\mathrm{A}_{2 \mathrm{~A}} \mathrm{R}$ agonists can penetrate spinal tissue and affect glia. In both $\mathrm{A}_{2 \mathrm{~A}} \mathrm{R}$ knock-out mice, and in our study of $\mathrm{A}_{2 \mathrm{~A}} \mathrm{R}$ agonists, neuropathic pain was attenuated, correlated with reduction in glial activation markers within the spinal cord (Bura et al., 2008). These seemingly contradictory findings may reflect that glial activation in knock-out 
mice was attenuated by a reduction in peripheral $\mathrm{A}_{2 \mathrm{~A}} \mathrm{R}$ activation, known to be pronociceptive (Taiwo and Levine, 1990; Doak and Sawynok, 1995; Khasar et al., 1995), thereby affecting inputs to the spinal cord. In contrast, in our study the glial activation was attenuated by direct $\mathrm{A}_{2 \mathrm{~A}} \mathrm{R}$ action within the spinal cord or, more likely, diffusion of CSF-derived IL-10, suppressing glial activation.

Our data are unique in that a single intrathecal $\mathrm{A}_{2 \mathrm{~A}} \mathrm{R}$ agonist injection produces remarkably enduring reversal of allodynia compared with previous reports in which $\mathrm{A}_{2 \mathrm{~A}} \mathrm{R}$ effects were only measured within the first $4 \mathrm{~h}$ (Lee and Yaksh, 1996; Poon and Sawynok, 1998; Yoon et al., 2005; Zahn et al., 2007), a time when our results show suboptimal impact on allodynia. Also, all previous $\mathrm{A}_{2 \mathrm{~A}} \mathrm{R}$ agonist studies have used nanomolar doses, below our lowest dose of ATL313 $(0.1 \mu \mathrm{M})$, a dose at which we did not detect an effect. Given that the effects from $\mathrm{A}_{2 \mathrm{~A}} \mathrm{R}$ activation take a few hours to achieve, timing of behavioral observations is critical. In a spinal nerve ligation model of neuropathic pain, intrathecal adenosine (nonselective adenosine receptor agonist) and an $A_{1} R$ agonist each attenuated allodynia for up to $24 \mathrm{~h}$, but no observations were reported after that (Lavand'homme and Eisenach, 1999; Zahn et al., 2007). Studies using the nonselective agonist NECA (5- $\mathrm{N}$-ethylcarboxamidoadenosine) suppressed thermal and tactile nociception in rats, dissipating within $1 \mathrm{~h}$ (DeLander and Hopkins, 1987). Systemic or intrathecal $A_{1} R$ agonists produce antihyperalgesia and antiallodynia, resolving within $2 \mathrm{~h}$ (Reeve and Dickenson, 1995; Lee and Yaksh, 1996; Sawynok, 1998; Curros-Criado and Herrero, 2005). Therefore, it is possible that activating neuronal adenosine receptors is short-lived versus the prolonged resetting of glial and/or CSF/meningeal immune cells after activation of $\mathrm{A}_{2 \mathrm{~A}}$ Rs. Reversal of allodynia, observed here, show that unlike IL-10 protein or IL-1 receptor antagonist (Milligan et al., 2005b; Ledeboer et al., 2007), which produce immediate effects, at least $4 \mathrm{~h}$ and possibly even $24 \mathrm{~h}$ is required to optimize the reversal of allodynia. This slow onset of reversal, and given that IL-10 neutralizing antibodies failed with coadministration with the $\mathrm{A}_{2 \mathrm{~A}} \mathrm{R}$ agonist, suggests that downstream mediators, such as IL-10, require time to develop and/or that immune cells need to be recruited and then phenotypically shifted to an antiinflammatory profile before a full benefit can occur for neuropathic pain.

The potential impact of $\mathrm{A}_{2 \mathrm{~A}} \mathrm{R}$ agonists as therapeutic agents has not yet been realized, at least for neuroinflammatory diseases (Yan et al., 2003), since too short a time course has been included or the in vivo models have limited the ability to identify the astounding duration of drug effect. We are currently investigating the effect of $\mathrm{A}_{2 \mathrm{~A}} \mathrm{R}$ agonists on a model of multiple sclerosis (experimental autoimmune encephalitis) and revealing dramatic improvement of motor function after single intrathecal $\mathrm{A}_{2 \mathrm{~A}}$ agonist administration (Loram et al., 2009), comparable with that seen after pDNA-IL-10 (Sloane et al., 2009a). If such observations are any indication, $\mathrm{A}_{2 \mathrm{~A}} \mathrm{R}$ agonists are potentially exciting candidates for the treatment of chronic pain and possibly other neuroinflammatory diseases.

\section{References}

Bennett GJ, Xie YK (1988) A peripheral mononeuropathy in rat that produces disorders of pain sensation like those seen in man. Pain 33:87-107.

Bura SA, Nadal X, Ledent C, Maldonado R, Valverde O (2008) A 2A adenosine receptor regulates glia proliferation and pain after peripheral nerve injury. Pain 140:95-103.

Cassada DC, Tribble CG, Young JS, Gangemi JJ, Gohari AR, Butler PD, Rieger JM, Kron IL, Linden J, Kern JA (2002) Adenosine A2A analogue im- proves neurologic outcome after spinal cord trauma in the rabbit. J Trauma 53:225-231.

Chacur M, Gutierrez JM, Milligan ED, Wieseler-Frank J, Britto LR, Maier SF, Watkins LR, Cury Y (2004) Snake venom components enhance pain upon subcutaneous injection: an initial examination of spinal cord mediators. Pain 111:65-76.

Chaplan SR, Bach FW, Pogrel JW, Chung JM, Yaksh TL (1994) Quantitative assessment of tactile allodynia in the rat paw. J Neurosci Methods 53:55-63.

Csoka B, Nemeth ZH, Selmeczy Z, Koscso B, Pacher P, Vizi ES, Deitch EA, Hasko G (2007a) Role of $A_{2 A}$ adenosine receptors in regulation of opsonized E. coli-induced macrophage function. Purinergic Signal 3:447-452.

Csoka B, Nemeth ZH, Virag L, Gergely P, Leibovich SJ, Pacher P, Sun CX, Blackburn MR, Vizi ES, Deitch EA, Hasko G (2007b) A2A adenosine receptors and $\mathrm{C} / \mathrm{EBP}$ beta are crucially required for IL-10 production by macrophages exposed to Escherichia coli. Blood 110:2685-2695.

Curros-Criado MM, Herrero JF (2005) The antinociceptive effects of the systemic adenosine A1 receptor agonist CPA in the absence and in the presence of spinal cord sensitization. Pharmacol Biochem Behav $82: 721-726$.

Dare E, Schulte G, Karovic O, Hammarberg C, Fredholm BB (2007) Modulation of glial cell functions by adenosine receptors. Physiol Behav 92:15-20.

DeLander GE, Hopkins CJ (1987) Involvement of A2 adenosine receptors in spinal mechanisms of antinociception. Eur J Pharmacol 139:215-223.

DeLeo JA, Yezierski RP (2001) The role of neuroinflammation and neuroimmune activation in persistent pain. Pain 90:1-6.

Doak GJ, Sawynok J (1995) Complex role of peripheral adenosine in the genesis of the response to subcutaneous formalin in the rat. Eur J Pharmacol 281:311-318.

Gordon S (2003) Alternative activation of macrophages. Nat Rev Immunol $3: 23-35$.

Hanisch UK, Kettenmann H (2007) Microglia: active sensor and versatile effector cells in the normal and pathologic brain. Nat Neurosci 10:1387-1394.

Hargreaves KM, Dubner R, Brown F, Flores C, Joris J (1988) A new and sensitive method for measuring thermal nociception in cutaneous hyperalgesia. Pain 32:77-88.

Harvey LO (1986) Efficient estimation of sensory thresholds. Behav Res Methods Instrum Comput 18:623-632.

Hasko G, Cronstein BN (2004) Adenosine: an endogenous regulator of innate immunity. Trends Immunol 25:33-39.

Hasko G, Szabo C, Nemeth ZH, Kvetan V, Pastores SM, Vizi ES (1996) Adenosine receptor agonists differentially regulate IL-10, TNF-alpha, and nitric oxide production in RAW 264.7 macrophages and in endotoxemic mice. J Immunol 157:4634-4640.

Hasko G, Pacher P, Deitch EA, Vizi ES (2007) Shaping of monocyte and macrophage function by adenosine receptors. Pharmacol Ther 113:264-275.

Khasar SG, Wang JF, Taiwo YO, Heller PH, Green PG, Levine JD (1995) $\mathrm{Mu}$-opioid agonist enhancement of prostaglandin-induced hyperalgesia in the rat: a G-protein beta gamma subunit-mediated effect? Neuroscience 67:189-195.

Kreckler LM, Wan TC, Ge ZD, Auchampach JA (2006) Adenosine inhibits tumor necrosis factor-alpha release from mouse peritoneal macrophages via $\mathrm{A} 2 \mathrm{~A}$ and $\mathrm{A} 2 \mathrm{~B}$ but not the $\mathrm{A} 3$ adenosine receptor. J Pharmacol Exp Ther 317:172-180.

Lavand'homme PM, Eisenach JC (1999) Exogenous and endogenous adenosine enhance the spinal antiallodynic effects of morphine in a rat model of neuropathic pain. Pain 80:31-36.

Ledeboer A, Wierinckx A, Bol J, Floris S, Renardel de Lavalette C, De Vries H, van den Berg T, Dijkstra C, Tilders F, van Dam A (2003) Regional and temporal expression patterns of interleukin-10, interleukin-10 receptor and adhesion molecules in the rat spinal cord during chronic relapsing EAE. J Neuroimmunol 136:94-103.

Ledeboer A, Jekich BM, Sloane EM, Mahoney JH, Langer SJ, Milligan ED, Martin D, Maier SF, Johnson KW, Leinwand LA, Chavez RA, Watkins LR (2007) Intrathecal interleukin-10 gene therapy attenuates paclitaxelinduced mechanical allodynia and proinflammatory cytokine expression in dorsal root ganglia in rats. Brain Behav Immun 21:686-698.

Lee YW, Yaksh TL (1996) Pharmacology of the spinal adenosine receptor 
which mediates the antiallodynic action of intrathecal adenosine agonists. J Pharmacol Exp Ther 277:1642-1648.

Loram LC, Harrison JA, Sloane EM, Taylor FR, Sholar P, Maier SF, Rieger J, Watkins LR (2009) Spinal adenosine modulation: enduring antiinflammatory action in neuroinflammatory disorders. Soc Neurosci Ab$\operatorname{str} 35: 171.2$

Lu Y, Sweitzer SM, Laurito CE, Yeomans DC (2004) Differential opioid inhibition of C- and A delta- fiber mediated thermonociception after stimulation of the nucleus raphe magnus. Anesth Analg 98:414-419.

Mantovani A, Sozzani S, Locati M, Allavena P, Sica A (2002) Macrophage polarization: tumor-associated macrophages as a paradigm for polarized M2 mononuclear phagocytes. Trends Immunol 23:549-555.

Milligan ED, Mehmert KK, Hinde JL, Harvey LO, Martin D, Tracey KJ, Maier SF, Watkins LR (2000) Thermal hyperalgesia and mechanical allodynia produced by intrathecal administration of the human immunodeficiency virus-1 (HIV-1) envelope glycoprotein, gp120. Brain Res 861:105-116.

Milligan ED, Maier SF, Watkins LR (2004) Sciatic inflammatory neuropathy in the rat: surgical procedures, induction of inflammation, and behavioral testing. Methods Mol Med 99:67-89.

Milligan ED, Sloane EM, Langer SJ, Cruz PE, Chacur M, Spataro L, WieselerFrank J, Hammack SE, Maier SF, Flotte TR, Forsayeth JR, Leinwand LA, Chavez R, Watkins LR (2005a) Controlling neuropathic pain by adenoassociated virus driven production of the anti-inflammatory cytokine, interleukin-10. Mol Pain 1:9.

Milligan ED, Langer SJ, Sloane EM, He L, Wieseler-Frank J, O'Connor K, Martin D, Forsayeth JR, Maier SF, Johnson K, Chavez RA, Leinwand LA, Watkins LR (2005b) Controlling pathological pain by adenovirally driven spinal production of the anti-inflammatory cytokine, interleukin10. Eur J Neurosci 21:2136-2148.

Milligan ED, Sloane EM, Langer SJ, Hughes TS, Jekich BM, Frank MG, Mahoney JH, Levkoff LH, Maier SF, Cruz PE, Flotte TR, Johnson KW, Mahoney MM, Chavez RA, Leinwand LA, Watkins LR (2006) Repeated intrathecal injections of plasmid DNA encoding interleukin-10 produce prolonged reversal of neuropathic pain. Pain 126:294-308.

Moore CC, Martin EN, Lee GH, Obrig T, Linden J, Scheld WM (2008) An A2A adenosine receptor agonist, ATL313, reduces inflammation and improves survival in murine sepsis models. BMC Infect Dis 8:141.

Nielsen CK, Ross FB, Lotfipour S, Saini KS, Edwards SR, Smith MT (2007) Oxycodone and morphine have distinctly different pharmacological profiles: radioligand binding and behavioural studies in two rat models of neuropathic pain. Pain 132:289-300.

Poon A, Sawynok J (1998) Antinociception by adenosine analogs and inhibitors of adenosine metabolism in an inflammatory thermal hyperalgesia model in the rat. Pain 74:235-245.

Reece TB, Kron IL, Okonkwo DO, Laurent JJ, Tache-Leon C, Maxey TS, Ellman PI, Linden J, Tribble CG, Kern JA (2006) Functional and cytoarchitectural spinal cord protection by ATL-146e after ischemia/reperfusion is mediated by adenosine receptor agonism. J Vasc Surg 44:392-397.

Reeve AJ, Dickenson AH (1995) The roles of spinal adenosine receptors in the control of acute and more persistent nociceptive responses of dorsal horn neurones in the anaesthetized rat. Br J Pharmacol 116:2221-2228.
Ren K, Dubner R (2008) Neuron-glia crosstalk gets serious: role in pain hypersensitivity. Curr Opin Anaesthesiol 21:570-579.

Ribeiro JA, Sebastiao AM, de Mendonca A (2002) Adenosine receptors in the nervous system: pathophysiological implications. Prog Neurobiol 68:377-392.

Sawynok J (1998) Adenosine receptor activation and nociception. Eur J Pharmacol 347:1-11.

Schiffmann SN, Fisone G, Moresco R, Cunha RA, Ferre S (2007) Adenosine A2A receptors and basal ganglia physiology. Prog Neurobiol 83:277-292.

Sloane E, Ledeboer A, Seibert W, Coats B, van Strien M, Maier SF, Johnson KW, Chavez R, Watkins LR, Leinwand L, Milligan ED, Van Dam AM (2009a) Anti-inflammatory cytokine gene therapy decreases sensory and motor dysfunction in experimental multiple sclerosis: MOG-EAE behavioral and anatomical symptom treatment with cytokine gene therapy. Brain Behav Immun 23:92-100.

Sloane E, Langer S, Jekich B, Mahoney J, Hughes T, Frank MG, Seibert W, Huberty G, Coats B, Harrison J, Klinman D, Poole S, Maier S, Johnson K, Chavez R, Watkins L, Leinwand L, Milligan E (2009b) Immunological priming potentiates non-viral antiinflammatory gene therapy treatment of neuropathic pain. Gene Ther 16:1210-1222.

Taiwo YO, Levine JD (1990) Direct cutaneous hyperalgesia induced by adenosine. Neuroscience 38:757-762.

Taylor RS (2006) Epidemiology of refractory neuropathic pain. Pain Pract 6:22-26.

Watkins LR, Maier SF (2003) Glia: a novel drug discovery target for clinical pain. Nat Rev Drug Discov 2:973-985.

Watkins LR, Hutchinson MR, Ledeboer A, Wieseler-Frank J, Milligan ED, Maier SF (2007) Norman Cousins Lecture. Glia as the "bad guys": implications for improving clinical pain control and the clinical utility of opioids. Brain Behav Immun 21:131-146.

Wieseler-Frank J, Jekich BM, Mahoney JH, Bland ST, Maier SF, Watkins LR (2007) A novel immune-to-CNS communication pathway: cells of the meninges surrounding the spinal cord CSF space produce proinflammatory cytokines in response to an inflammatory stimulus. Brain Behav Immun 21:711-718.

Yamamoto S, Nakanishi O, Matsui T, Shinohara N, Kinoshita H, Lambert C, Ishikawa $\mathrm{T}$ (2003) Intrathecal adenosine $\mathrm{A} 1$ receptor agonist attenuates hyperalgesia without inhibiting spinal glutamate release in the rat. Cell Mol Neurobiol 23:175-185.

Yan L, Burbiel JC, Maass A, Muller CE (2003) Adenosine receptor agonists: from basic medicinal chemistry to clinical development. Expert Opin Emerg Drugs 8:537-576.

Yoon MH, Bae HB, Choi JI (2005) Antinociception of intrathecal adenosine receptor subtype agonists in rat formalin test. Anesth Analg 101: 1417-1421.

Zahn PK, Straub H, Wenk M, Pogatzki-Zahn EM (2007) Adenosine A1 but not A2a receptor agonist reduces hyperalgesia caused by a surgical incision in rats: a pertussis toxin-sensitive G protein-dependent process. Anesthesiology 107:797-806. 